\title{
The Choice of Debt Source by UK Firms
}

\begin{abstract}
We examine the choice of borrowing source between public debt, syndicated bank loans, bilateral bank loans, and non-bank private debt. Using a sample of 400 non-financial firms over 2000-2012, we find strong support for the reputational theory of borrowing source. Larger firms are more likely to borrow in public debt markets. Bank dependent firms are less likely to borrow in public debt markets and choose between bank and non-bank private debt based on maturity, collateral available to lenders, and other firm characteristics. These results are consistent with the role of borrower reputation being the primary determinant of borrowing source for UK listed firms.
\end{abstract}

JEL Classification: G20, G21, G32

Keywords: debt policy, public debt, bilateral loans, syndicated loans, non-bank private debt 


\section{INTRODUCTION}

Theoretical research assigns an important role to the debt source in a firm's capital structure decision. First, Diamond's (1991) reputational theory proposes that firms build reputation in credit markets through borrowing and repaying private debt initially, and that repeating this process over time allows firms to build a reputation in credit markets. This results in lower borrowing costs. Second, bank monitoring can reduce asymmetric information costs for firms that produce less information than lenders in public debt markets optimally demand, as banks can more closely scrutinize the firm to monitor cash flows (Fama, 1985). Finally, bank debt is more easily renegotiated in the event of financial distress given that bank lenders have more information on the firm's cash flows and investment opportunities to decide whether liquidation is optimal (Chemmanur and Fulghieri, 1994; Yosha, 1995). ${ }^{1}$

In this paper we empirically investigate theories of debt source choice by examining their determinants in a UK setting. We use the distinctive features of the UK market for corporate lending to extend the literature on the choice of borrowing source. UK firms historically have placed a greater dependence on bank debt than public bond issues. Data from the Bank of England $(2009,2012)$ illustrates that UK firms continue to borrow predominately from banks and show a large increase in the use of syndicated bank loans, relative to bilateral loans, in recent years. Moreover, the underdeveloped nature of the public bond market in the UK creates a potentially important role for non-bank private debt as an alternative bond source in a firm's financing choice in the UK (Breedon, 2012). Diamond (1991) refers to the importance of nontraditional debt sources for low credit quality firms screened out of bank lending and public bond markets. Given the description of non-bank private debt as combining the features of low-grade

\footnotetext{
${ }^{1}$ Johnson (1997) and Denis and Mihov (2003) provide detailed reviews of the theoretical determinants of borrowing source.
} 
public debt and bank debt in Denis and Mihov (2003), we expect that non-bank private debt can represent an important financing source for UK firms.

Using a sample of UK non-financial firms in the FTSE-350 index of the London Stock Exchange (LSE) over the period 2000 to 2012 we consider the determinants of both the existing balance sheet debt and the source of finance for new debt issuance. In doing so, we distinguish between borrowing from public debt markets, bank loans (both bilateral and syndicated), and non-bank private debt. Focusing on existing and new debt issues allows us to consider the importance of firm and debt characteristics, credit market conditions, and a firm's financing history in determining incremental financing choices.

Our study extends the literature on the choice of debt source in a number of areas. First, we consider a broader range of bank lending sources for both existing balance sheet debt and marginal debt financing choices than has been examined in the literature. Examining incremental financing decisions allows for an improved understanding of the role of firm, loan and economic characteristics, and a firm's borrowing history in determining the source of borrowing than is possible when examining previously issued debt on the firm's balance sheet. In addition to splitting debt financing between bonds and loans, we separate bonds between public and nonbank private bonds and new bank loans between syndicated and bilateral lending agreements.

Second, we use this expanded range of borrowing sources to examine the impact of borrower reputation on a firm's choice of debt source. The initial empirical research building on Diamond's (1991) asymmetric information based model of borrower reputation proposes that firms borrow from public and private debt sources. This research has developed over time to consider the role of reputation in accessing non-bank private debt (Johnson, 1997; Denis and Mihov, 2003; Arena, 2011). However few studies distinguish between bilateral and syndicated 
bank loans and none, to our knowledge, in the context of the choice across a range of debt sources. ${ }^{2}$ We argue that syndicated loans combine elements of traditional relationship lending associated with bilateral bank loans and transaction based lending more commonly associated with raising capital in bond markets. In this sense, syndicated loans can be viewed as an extension of Diamond's (1991) reputational theory of borrowing source choice. Syndicated loans are more easily monitored than public bonds, but less so than bilateral lending agreements.

Finally, we extend the literature by examining the impact of the global financial crisis on the determinants of a firm's borrowing source. Our sample covers the period of credit expansion prior to 2008 and the reported collapse in the availability of bank financing worldwide. Given the expected reduction in bank lending surrounding this period we examine whether the financial crisis had a direct impact on balance sheet debt source and the choice of marginal borrowing source. We also consider whether and how the determinants of borrowing source have changed around the financial crisis.

When choosing amongst debt securities, we find that the largest debt issues are loans syndicated across a number of lending banks. However, our results also show that syndicated and bilateral loans have similar maturities. Public bonds and non-bank private debt have longer maturities. We find that the maturity of a firm's existing debt is closely related to its marginal financing choices as firms with a higher proportion of existing long-term debt are more likely to borrow in bond markets in their incremental financing decisions.

\footnotetext{
${ }^{2}$ See Houston and James (1996) and Hadlock and James (2002) for US evidence on the choice between public and private securities and Barnes and Cahill (2005) and Antoniou et al. (2008) for UK firms. A small number of studies have examined the choice of public bond financing relative to syndicated bank loans (Altunbas et al., 2009) and syndicated loans relative to bilateral loans (Dennis and Mullineaux, 2000; Marsh, 2006; Sufi, 2007). Gomes and Phillips (2012) examine the choice between public and private markets, and amongst straight debt, equity, and convertible securities. However, their private category aggregates syndicated and bilateral loans with Rule 144-A privately placed bonds. None of these studies examine syndicated loans across a broad spectrum of debt choices.
} 
Consistent with Diamond's (1991) theoretical predictions, we find that firm size and collateral are the most important firm characteristics in determining debt source. Larger firms are more likely to borrow in public debt markets and firms with little collateral are screened out of traditional sources and forced to borrow in non-bank private markets. Our findings on the importance of fixed assets as collateral also support theories of debt source based on efficiency of liquidation where firms with difficult to value intangible assets are more likely to choose private debt sources. We find other firm characteristics affect existing debt source or incremental financing choices, but they are not consistent across our results.

Reputation effects in credit markets are also evident in the impact of a firm's borrowing history on marginal financing choice. We find that firms that are characterized as bank dependent are significantly less likely to borrow in public debt markets relative to other financing sources. Prior to the global financial crisis we find that syndicated bank loans act as intermediate step to public debt markets for bank dependent firms, but this effect is not present in the post-crisis period where bilateral loans increased in popularity for our sample of large firms.

We find that the financial crisis has impacted on the determinants of borrowing source. Firm age and industry specialization, which are associated with borrower reputation and the need for ease of renegotiation of lending agreements, are important determinants of borrowing source in the post-crisis period, but were unrelated to borrowing source pre-crisis. Moreover, within the crisis period non-bank private debt is more frequently issued when economic growth is weak, which suggests that banks were reluctant to lend at this point in time. This supports Diamond's (1991) description of non-traditional lending sources for firms that have been screened out of bank lending markets. 
The remainder of this paper is structured as follows. Section 2 provides a discussion of the sample data. Our results for existing debt financing are in Section 3. Section 4 reports our findings for incremental debt financing decisions. Section 5 examines the impact of the financial crisis on firm's debt sourcing decisions. Section 6 discusses further analysis to confirm the robustness of our core findings. Finally Section 7 provides a summary and concludes.

\section{SAMPLE CONSTRUCTION AND VARIABLE DEFINTIONS}

\section{(i) Choice of Borrowing Source}

In this section we explain the choice of borrowing sources that we consider in a firm's marginal financing decision. Public debt is a bond security where firms typically agree to repay fixed coupon payments over the life of the bond and the par value at maturity. A commonality in theories of debt sourcing is that the bond is sold to a wide group of passive investors who are not expected to monitor the loan (Diamond, 1991). However, competition amongst a larger number of capital providers is expected to result in public debt markets offering lower cost debt financing than private debt markets, including bank lending. Given the unmonitored nature of public debt, firms borrowing in this market are expected to be amongst the largest and most reputable credit market participants (Houston and James, 1996; Gomes and Phillips, 2012).

Non-bank private debt is privately placed debt where the issuing firm raises funds directly from private investors that are not identified as banks, such as insurance firms, pension funds, and other private investor groups. Non-bank private debt most commonly takes the form of a bond where the borrower pays a coupon at regular intervals and repays the par value of the bond at redemption, but unlike a public bond the debt is not registered on a public exchange. Kwan and Carleton (2010) state that public bonds and non-bank private debt differ in three main 
ways: (i) the design of bond covenants, (ii) credit monitoring, and (iii) the relative ease of renegotiation. Denis and Mihov (2003) describe non-bank private debt as an intermediate instrument that combines elements of bank debt and low-grade public bonds. ${ }^{3}$

Traditional theories of debt sourcing describe bank loans as a bilateral agreement between a lender and a borrower where interest and principal is repaid over the life of the loan. The single party nature of the agreement allows for closer monitoring and negotiating flexibility in the event of default. Diamond (1991) argues that firms seeking to build a relationship with a bank can borrow on bilateral terms. Firms will also choose to borrow from a single lender to maintain a comparative advantage when they are concerned about competitors acquiring proprietary information (Bushman et al., 2010).

Syndicated loans involve two or more lending banks agreeing to provide funding to the borrowing firm and each member of a lending syndicate is a direct lender to the borrower. Each syndicate has a lead or managing agent who is responsible for arranging the loan, coordinating documentation, and administrating the loan repayment. In a syndicated loan it is typical for the borrowing firm to form a relation with the lead agent, who in turn forms a relation with other lenders in the syndicate (Ball et al., 2008). Monitoring and due diligence by the lead agent reduces information asymmetries between borrowers and members of the lending syndicate (Bushman and Wittenberg-Moerman, 2012). Drucker and Puri (2009) argue that syndicated lending agreements are typically for larger amounts than bilateral loans because they allow lenders to reduce their exposure to credit risk. Syndicated loans can also be structured with fewer and more concentrated lenders to increase monitoring efficiency and ease of renegotiation for high credit risk firms (Sufi, 2007). However, syndicated loans are expected to be subject to free

\footnotetext{
${ }^{3}$ See Chandra and Nayar (2008) and Kwan and Carleton (2010) for a detailed discussion of privately placed debt.
} 
rider and information asymmetry concerns relative to bilateral loans and therefore share elements of both public debt and bilateral loans (Boot, 2000; Dennis and Mullineaux, 2000).

These differences lead us to expect that firms borrowing from either bilateral or syndicated lending facilities display different firm or loan characteristics. Borrowing through syndicated loans allows for the benefits of lender monitoring by the lead agent in the syndicate, but allows lenders to diversify the risk of default and increase loan amounts to borrowing firms (Dennis and Mullineaux, 2000; Godlewski et al., 2012). Free-rider problems imply that monitoring by a dispersed syndicate is less effective than by a single bank lender, but more effective than monitoring by a widely dispersed group of public bondholders (Boot, 2000; Ball et al., 2008). Syndicated lending can also allow borrowing firms to diversify lending sources and avoid the hold-up problems of single lender loans (Rajan, 1992; Houston and James, 1996).

\section{(ii) Sample Construction}

We construct our sample by including all firms listed in the FTSE-350 index of the LSE during the period 2000 to 2012. Firms are included in our sample only for those years where they are listed in the FTSE-350. The large size of these firms allows them access to a wider variety of financing sources than for small and medium sized enterprises, for which economies of scale in information production and fixed issuance costs act as barriers to entry to public bond markets. Focusing on large firms allows us to consider factors beyond information production that determine a firm's optimal debt source. ${ }^{4}$ Excluding financial and utility firms produces an initial sample of 2,836 firm-year observations across 400 firms for which we collect data on existing debt ownership and borrowing source for debt issuance.

\footnotetext{
${ }^{4}$ Dennis and Mullineaux (2000) and Hadlock and James (2002) provide detailed analyses of information asymmetry problems and debt sourcing decisions.
} 
For each of the 400 firms in our sample, we manually collect data on outstanding debt from public, bank, and non-bank private lenders from the footnotes to each firm's financial statements for each reporting year from 2000 to 2012. Firms classify existing debt by loan type and maturity, but not explicitly by lender source. This allows us to distinguish between previously issued public and privately held debt. However, in many cases we are unable to distinguish between non-bank private and bank debt, nor between syndicated and bilateral bank loans. Following Johnson (1997) we classify all private debt as non-bank private debt unless it is explicitly defined as bank debt in the notes. ${ }^{5}$ We find that ninety percent of firm-year observations have some outstanding debt on their balance sheet, providing a sample of 2,563 firm-year observations across 399 of the 400 sample firms. This is the starting sample we use to examine the determinants of existing debt source in Section 3 of this paper.

To capture the incremental choice of debt source for our sample firms, we use Nexis UK to manually search for announcements of issuances of public debt, bilateral and syndicated bank debt and non-bank private debt. ${ }^{6}$ Announcements of private debt issuance are classified as bank debt only where banks are explicitly mentioned as the lending institution. We relate the source of borrowing for a firm's marginal financing choice over the subsequent financial year, time $t+1$, to firm characteristics and borrowing history at time $t$. Therefore our sample period for incremental borrowing decisions is from 2001 to 2013 . We use this sample to analyze the determinants of incremental borrowing decisions in Section 4 of this paper.

\footnotetext{
${ }^{5}$ One problem with this approach is that it can understate the use of bank debt. However, as $81 \%$ of sample private debt announcements are classed as bank debt is appears that this categorisation picks up a significant volume of bank debt.

${ }^{6}$ Following Hadlock and James (2002), we search for articles on debt issues using the following keywords: "line of credit," "loan agreement," "bank loan," "credit agreement," "credit line," "credit facility," "credit extension," "new loan," "loan renewal," "loan revision," "loan extension," "term loan," " debt issue," "debt offer," "public debt issue," and "public debt offer." To augment the sample, the following keywords are also employed: "bond," "bond issue," "debt notes," "loan facility," "working capital facility," "private placement," and "overdraft."
} 
We initially identify bank loans, both syndicated and bilateral, through stock exchange announcements and news reports from Nexis UK. Maskara and Mullineaux (2011) find that approximately $25 \%$ of US bank loans are announced in the media, which raises concerns of selection bias if studies rely exclusively on news reports to collect data on debt source. Therefore, we supplement our sample of news reported bank loan announcements with loan data for our sample firms reported by DealScan. We find an initial sample of 810 announced bank loans in Nexis UK, which comprises over $97 \%$ of the loans for sample firms contained in DealScan. We add 24 unannounced bank loans from DealScan providing a final sample of 834 loans. $^{7}$ Of these, 667 loans are syndicated and the remaining 167 are bilateral lending agreements.

We follow this approach to collect announcements of non-bank private debt issuance. Nexis UK provides an initial sample of 194 announced non-bank private loans, which we crossreference against the Private Placement Letter database for each of our sample firms. We find that our sample of non-bank private loan announcements comprise $98 \%$ of the loans available in Private Placement Letter, and add 4 unannounced non-bank private loans to our sample, producing a final sample of 198 loans.

We collect data on public debt issuance from Nexis UK, Thomson ONE and Datastream. We find an initial sample of 333 announced public bonds in Nexis UK. We then cross-reference our sample of announced public bonds with those from Thomson ONE and DataStream and find no additional announcements of public debt issuance through these sources. Therefore, across all borrowing sources we have a sample of 1,365 marginal financing announcements.

\section{(iii) Variable Definitions}

${ }^{7}$ Our initial Nexis UK sample contained only one loan that was not included on the DealScan database. 
Johnson (1997) classifies theoretical research on the determinants of debt source across three broad categories: models based on monitoring and information costs, models based on efficiency of liquidation, and models based on borrowers' reputation and incentives to repay. Empirically, the distinction between these areas is frequently blurred as variables can proxy for several theoretical concepts. In this section we discuss the empirical variables used in our study.

In Section 3 we relate firm characteristics to the proportion of existing balance sheet debt outstanding from each borrowing source described above. In each case the dependent variable is the amount of debt outstanding from an individual borrowing source divided by total debt outstanding on the balance sheet. The independent variables are measured contemporaneously to the dependent variables.

In Section 4 we relate binary dependent variables of the source of borrowing for incremental security issuance decisions to firm and loan characteristics, economic and credit market conditions, and a firm's borrowing history at the time of issuance. Firm characteristics, borrowing history, economic conditions and firm performance are measured in the period prior to the new loan announcement. Loan characteristics and credit market spreads are taken from the loan announcement itself.

\section{(a) Determinants of Existing Debt Source}

Firm size. Prior literature is unanimous in finding that firms borrowing in public debt markets are larger than those that borrow from private sources (Hadlock and James, 2002). This is supportive of information production and borrower reputation theories of debt source, where larger firms naturally produce the information required to borrow in public markets and their size is correlated with reputation in credit markets. For private borrowing Denis and Mihov (2003) find 
no difference in firm size between bank and non-bank private debt issues. We measure Firm size as the book value of total assets (Emillions) indexed to 2000 sterling figures using the UK consumer price inflation index.

Firm age. Older firms are expected to have built a reputation in credit markets that allows them to access more competitive public bond markets with lower yields (Diamond, 1991). Consistent with this, Krishnaswami et al. (1999) and Hadlock and James (2002) find a positive relation between firm age and the use of public debt. Johnson (1997) also finds a positive relation between firm age and the proportion of total debt from public bonds, but a negative relation between age and the proportion of bank debt, and no relation between age and non-bank private debt. We use Firm age as a measure of reputation in credit markets, where age is measured from the date of incorporation.

Fixed assets ratio. Offering tangible assets as collateral is viewed as a sign of a lower risk borrower (Rajan and Zingales, 1995). Johnson (1997) finds that the proportion of both bank debt and public debt outstanding increases with the fixed assets ratio. The proportion of non-bank private debt outstanding is negatively related to this ratio. Denis and Mihov (2003) find that firms are more likely to issue public debt if they have a higher proportion of fixed assets, but find no distinction between bank and non-bank private debt. The Fixed assets ratio is defined as the ratio of plant, property, and equipment to total assets.

Specialized industry. Firms with specialized assets and who provide ongoing after-sales service for their products, such as maintenance and warranties, are expected to suffer to a greater extent from indirect costs of bankruptcy and therefore prefer easier to renegotiate private debt. Applying this to debt sourcing decisions, Johnson (1997) finds that firms operating in specialized 
industries have a lower proportion of public debt outstanding. ${ }^{8}$ We use a dummy variable for firms operating in Specialized industries that takes the value of one for firms in the durable goods industry with SIC codes between 3400 and 3999, and zero otherwise.

Investment opportunities. Empirical evidence on the impact of growth opportunities on the choice of debt source is mixed. Krishnaswami et al. (1999) report a positive relation between a firm's future growth opportunities and the use of private debt, consistent with firms with higher growth opportunities finding it beneficial to use a banking relationship. However Hadlock and James (2002) and Denis and Mihov (2003) find no evidence of a relation between growth opportunities and the choice of debt source. We measure Investment as the sum of capital expenditures and research and development spending divided by total assets.

Earnings volatility. Greater earnings volatility implies less certainty in a firm's ability to meet future interest obligations and creates a preference for private debt that can be renegotiated to preserve asset value. Johnson (1997) finds a negative relation between public debt and earnings growth volatility. Similarly Houston and James (1996) find that greater stock price volatility reduces the likelihood of firms borrowing in public debt markets. Following Clubb and $\mathrm{Wu}$ (2014), Earnings volatility is defined as the standard deviation of pretax income minus income taxes for the previous three years divided by the average total assets for the period. ${ }^{9}$

Firm performance. Diamond (1991) argues that less profitable firms typically have weaker credit market reputations and are more likely to take on riskier projects. This leads to unprofitable firms being unable to access public bond markets. Denis and Mihov (2003) find that both bank and non-bank private borrowers are less profitable than firms that have public debt outstanding. Hadlock and James (2002) find that firms issuing bank debt have significantly lower

\footnotetext{
${ }^{8}$ Specialised industries are defined as firms in the machinery, computing, and technology sectors.

${ }^{9}$ The results presented in our paper are robust to the alternative cash flow volatility measure presented in Clubb and $\mathrm{Wu}$ (2014) and the earnings volatility measure used in Johnson (1997).
} 
stock price returns than public debt issuers in the 12 months prior to borrowing. We measure firm performance as Return on assets, which we define as the ratio of earnings before interest, tax, depreciation and amortization to total assets.

Leverage. Johnson (1998) argues that the use of private debt increases with firm leverage. This arises where bank debt can mitigate both information asymmetry and the problem of asset substitution, increasing the willingness of banks to lend to familiar firms. Borrowers with a high risk of default choose a private lender who has a reputation for making efficient liquidation decisions. However, Diamond (1993) argues that the heightened chance of liquidation and frequent renegotiation brought on by private borrowing can encourage the use of unmonitored public debt by firms that are highly leveraged. Faulkender and Petersen (2006) show that firms should have less debt in their capital structure if they can only raise debt from private sources or if they are limited in the amount of debt they can issue in public markets. Denis and Mihov (2003) find that firms issuing public debt have higher leverage than firms issuing bank and nonbank private debt. Johnson (1997) finds that the proportions of public debt and bank debt increase with leverage, but non-bank private debt is found to be negatively related to leverage. We measure Leverage as the book value of total debt divided by the book value of total assets.

(b) Additional At-Issue Determinants of the Incremental Debt Financing Source

Existing debt source. To the extent that firm characteristics, such as size, asset type, and credit market reputation change slowly over time, firms are expected to borrow from existing providers. Consistent with this, Hadlock and James (2002) and Denis and Mihov (2003) find that firms with outstanding public debt are more likely to raise new loans in this market and bank dependent firms are more likely to raise new loans from banks. Denis and Mihov (2003) find no 
clear link from existing debt finance to the use of new non-bank private loans, suggesting that non-bank private loans represent deviations from regular financing patterns. We use two key variables to examine existing debt source. Proportion long-term debt is the fraction of existing debt on the firm's balance sheet with a maturity of greater than one year. Following Hadlock and James (2002) we define Bank dependent as a dummy variable that takes the value one when the proportion of outstanding bank debt is greater than the median proportion of outstanding bank debt (0.71) for all sample firms and the firm has no public debt outstanding, and zero otherwise. In further unreported analysis we also include a binary variable, Public debt outstanding, which takes the value one if the firm has any public debt outstanding on its financial statements, and zero otherwise.

Credit quality. We use financial distress as an indirect measure of borrowing firm credit quality. Carey et al. (1998) find that loans to riskier investment projects tend to be made by nonbank private lenders. Denis and Mihov (2003) observe that high credit quality firms borrow from public sources, firms with moderate credit quality borrow from banks, and that for low credit quality firms non-bank private debt meets their debt financing requirements. Following Hovakimian and Titman (2004), Credit quality is based on low interest coverage and is a dummy variable set to one where the interest coverage ratio is less than 0.8 , or less than 1 in two consecutive years. Interest coverage is calculated as EBITDA divided by total interest payable. ${ }^{10}$

Loan size. Firms issuing public debt tend to be larger firms issuing larger amounts that suffer less from information asymmetry, and consequently require less monitoring (Denis and Mihov, 2003). In contrast, issues of private debt, particularly bank debt, are most attractive for firms issuing smaller amounts. Blackwell and Kidwell (1988) find that, on average, private debt

\footnotetext{
${ }^{10}$ Our results are robust to using the Taffler Z-score measure for UK firms (see Agarwal and Taffler, 2008)
} 
issues are half the size of public issues. ${ }^{11}$ For private debt Denis and Mihov (2003) find that nonbank private loans are generally smaller than bank loans. The growth of the syndicated loans market has altered this traditional concept; firms wishing to borrow large amounts of debt can now raise the debt from a group of banks or other financial institutions (Dennis and Mullineaux, 2000). We define Loan size as the value of the loan issued indexed for consumer price inflation to the year 2000 .

Loan maturity. Much of the literature on loan maturity complements the literature on the determinants of debt sourcing. For example, borrowing at shorter maturities is associated with ease of renegotiation in the event of financial distress and ease of monitoring managerial decision making at the point where loans are rolled over (Barclay and Smith, 1995; Dang, 2011). As such, public issues of debt have longer maturities than non-bank private loans and bank loans (James, 1987; Johnson, 1997). Loan maturity is measured as the number of years to maturity for each loan.

Economic performance and credit market conditions. Blackwell and Kidwell (1988) and Cantillo and Wright (2000) find an important role for credit market conditions in debt source. Therefore we include three measures of economic performance and prevailing credit market conditions that could impact the choice of debt source. We use lagged quarterly GDP to examine whether prevailing economic conditions impact on debt source. $\triangle G D P$ is the change in gross domestic product over the quarter before the debt announcement is made. We include Libor and the term structure of interest rates to determine whether firms are more likely to borrow from longer term public sources or shorter term private sources dependent on current and expected future interest rates. Libor is the United Kingdom Interbank 3-month offer rate on the date that

\footnotetext{
${ }^{11}$ It would be expected that lenders of larger amounts are more likely to carry out more thorough pre-loan diligence than lenders of smaller loans.
} 
the announcement is made. Term spread is the spread between 10-year UK Government bonds and 3-month T-bills, again measured on the date that the loan announcement is made.

\section{ANALYSIS OF EXISTING DEBT MIX}

\section{(i) Summary Statistics on Existing Debt Mix}

Table 1 presents summary statistics for the full sample of 2,563 firm-year observations. The data are complete for debt source data collected from the financial statements, but we lose some observations when matching to Worldscope for accounting and economic data. The mean (median) leverage ratio is $0.30(0.23)$. This figure is higher than previously reported for UK firms by Rajan and Zingales (1995), reflecting the larger size of firms in our sample. 42\%, 43\%, and $95 \%$ of firm-year observations have some public, non-bank private, or bank debt outstanding respectively. The figure of $43 \%$ non-bank private debt outstanding is almost identical to the figures in Breedon (2012), which lends support to our classification of private debt as non-bank unless it is explicitly identified as bank debt in the financial statements.

[Insert Table 1 about here]

The importance of bank debt for our sample of UK firms is reinforced when we consider the relative importance of debt source to total debt. The mean (median) bank debt to total debt ratio is $0.60(0.71)$. Public debt is $24 \%$ of total debt on average and non-bank private debt is $15 \%$

of total debt. The median firm has no public debt or non-bank private debt outstanding. Public and non-bank private debt becomes slightly more important when we focus on long-term debt, but even here bank debt remains the dominant source of debt.

Our summary statistics emphasize the limited use of the public bond market in the UK relative to the US and we expect syndicated bank loans to provide an important alternative debt 
source for our sample firms. Comparison with earlier UK studies of bank debt is difficult given inconsistency in classification of bank and non-bank private debt, but our total private debt figure of $75 \%$ is lower than in Antoniou et al. (2008), who find that private debt comprises $95 \%$ of total debt in their UK sample; this difference is most likely due to the size of firms in the respective samples.

\section{(ii) Determinants of Existing Debt Sourcing Mix}

Table 2 reports summary statistics for borrowing firms based on their main source of debt finance. We report this data for the sub-sample of 2,248 firm-years where we have complete data across all dependent and explanatory variables used in subsequent regression analysis of the determinants of existing debt source. The main source of debt is defined as the source that represents the highest proportion of debt ownership amongst public debt, bank debt, and nonbank private debt. Firm years are allocated to sub groups according to the largest proportion of their reported debt in that year: "mostly public", "mostly bank" and "mostly non-bank private." We use superscripts 1,2 , and 3 to denote that firm characteristics for firms borrowing predominantly from one debt source are significantly different at the $5 \%$ level or greater from those borrowing predominantly from other sources in the corresponding numbered columns. ${ }^{12}$

Firms with predominately public debt outstanding are older and larger than firms that have mostly bank debt outstanding. The average firm that relies mainly on public debt has been incorporated for 49.88 years and has total assets of $£ 6,973$ million, compared to 39.18 years and, $£ 1,336$ million for firms that use mostly bank debt. Non-bank private borrowers are older and

\footnotetext{
${ }^{12}$ For example, the mean asset value of $£ 1,336$ million for firms borrowing predominantly from banks is highlighted with the superscripts 1 and 3 . This denotes that the mean value is significantly different at the $5 \%$ level from both the reported mean assets of $£ 6,973$ million in column 1 for firms predominantly borrowing from public debt markets and from the mean assets of $£ 4,823$ million in column 3 for firms predominantly borrowing from non-bank private debt sources.
} 
larger than firms primarily borrowing from banks, but are smaller at the median level than firms that mainly use public debt. Firms that rely mainly on public debt have higher fixed assets ratios than firms that use primarily bank debt, who in turn have more tangible assets than firms relying mainly on non-bank private debt. These firms, with low levels of collateral to secure against their debt, may have been screened out of borrowing in public debt markets (Diamond, 1991).

[Insert Table 2 about here]

Sample firms that depend on primarily public debt also have higher leverage than those that rely mainly on non-bank private debt or bank debt. We find that firms operating in specialized industries have a lower proportion of public debt outstanding than bank debt. We find some evidence that firms that are more reliant on bank debt have better investment opportunities. These firms can benefit from the continuing nature, and flexibility, of a banking relationship (Boot, 2000). Firms that borrow mostly from banks outperform firms relying on public or non-bank private debt as their main source of debt financing. We find no evidence that firms are more likely to use a particular debt source based on their earnings volatility.

In advance of our multivariate analysis we examine correlations amongst explanatory variables to investigate concerns surrounding multicolinearity. Table 3 provides information on the correlations between our explanatory variables. As expected, we find a positive correlation between firm size, firm age and asset tangibility, which highlights that older firms are larger and tend to have fewer intangible assets than younger and smaller firms. The table also highlights a negative relation between measures of investment intensity and risk, and asset tangibility. The highest reported correlation is 0.3269 (between Fixed assets ratio and Investment). We also estimate variance inflation factors (VIFs) for our explanatory variables and find that no 
individual VIF is above 1.23. Collectively, these findings suggest that multicollinearity does not severely affect our regressions analysis in this section.

\section{[Insert Table 3 about here]}

We extend our univariate analysis to estimate Tobit regressions of debt source determinants in Table 4 where the dependent variable is censored between zero and one. Tobit models are frequently used in the debt sourcing literature (Houston and James, 1996; Johnson, 1997) and are appropriate here given that the median firm has no public or non-bank private debt outstanding. However, endogeneity concerns surrounding the joint determination of leverage and borrowing source mean that a basic Tobit model is not appropriate for our empirical testing. Johnson (1997) notes that leverage is empirically related to many of the same firm size, risk, and investment opportunity characteristics that are expected to be correlated with debt source, suggesting that they are jointly determined in practice.

We use the ratio of cash to total assets as our instrumental variable in first stage regressions of the determinants of leverage. We suggest that cash to total assets is a valid instrument for debt source both theoretically and empirically. Theoretically, the pecking order theory (Myers, 1984) predicts a negative relation between cash holdings and leverage. Firms accumulate cash over time and pay back debt as it becomes due. This allows firms to avoid future equity issues, which are expensive due to adverse selection costs. Opler et al. (1999) find that cash holdings are negatively related to leverage. Empirically, we find that cash to total assets is negatively correlated with firm leverage but is uncorrelated with the proportion of existing debt borrowed from any of the sources we examine in this study, and the choice of debt source in marginal financing decisions. Given this, we use cash to total assets as an instrument in our first stage leverage regressions. 
Following our first-stage prediction of leverage, we specify a second-stage Tobit model where the dependent variable Debt source is defined as the ratio of debt from any individual source divided by total debt outstanding. We also report results separately for total debt and for long-term debt with a maturity greater than one year given the correlation between debt source and maturity noted by Johnson (1998) amongst others. All firm characteristics are as defined previously in Section 2 (iii). The regressions include year dummies, but we do not report these for brevity. We report $p$-values for standard errors clustered by firm and partial $F$-statistics for the first-stage regression of leverage ratios. ${ }^{13}$

[Insert Table 4 about here]

Models 1 and 4 of Table 4 present results where the proportion of public debt is the dependent variable. We find that public debt use is significantly positively related to firm size and earnings volatility. We also find weak evidence in model 4 that long-term public debt use increases with firm age. The results for firm size and age are consistent with the predictions of theories of debt source based on information asymmetry and borrower reputation (Diamond, 1984, 1991; Fama, 1985). However, our findings for earnings volatility are inconsistent with the liquidation efficiency hypothesis where risk should be negatively correlated with public debt given the difficulty in renegotiating across dispersed public bondholders. This finding is consistent with Barnes and Cahill (2005) for their UK sample. We find no relation between leverage and public debt use, which is inconsistent with Johnson (1997).

By construction, any debt that is not publicly traded is private. As such, we can reverse our results for public debt to interpret the relation between firm characteristics and private debt, i.e., the proportion of debt from private sources is negatively related to firm size. We expand on

\footnotetext{
${ }^{13}$ Our results are robust to re-estimating these tests using instrumental variable two-stage least squares (2SLS) regressions, rather than Tobit specifications.
} 
this and separate private debt between borrowings from bank and non-bank private sources in regression models 2-3 and 5-6 of Table 4. We find that bank debt decreases with firm size (models 2 and 5), but non-bank private debt increases with size (models 3 and 6). This supports the arguments of Carey et al. (1993), who suggest that non-bank private debt fills a gap between public bond markets and bank debt. Earnings volatility is negatively related to the proportion of bank debt outstanding. Either banks are reluctant to provide finance to risky borrowers or risky firms are reluctant to borrow from banks who act as active monitors of their risky investment projects and cash flows. We find evidence of bank debt increasing with leverage and weak evidence that long-term non-bank private debt decreases with leverage. Our findings for bank debt are consistent with Johnson (1997) who argues that highly leveraged firms can benefit from monitoring by bank lenders.

Our analysis of the determinants of existing debt sources provides general support for the reputational theory of Diamond (1991). Larger firms are expected to have built stronger reputations in credit markets, which allows for easier access to public bond markets. We find little consistent support for theories of debt source choice based on efficiency of liquidation surrounding fixed and specialized assets as measures of loan collateral and indirect costs of bankruptcy.

\section{ANALYSIS OF INCREMENTAL FINANCING DECISIONS}

\section{(i) Incremental Financing Choice Announcements}

In this section we extend our analysis to consider the determinants of incremental debt financing decisions for the sub-sample of firm-years when sample firms issue new loans or renew existing loan agreements. This allows us to consider issuing firm and loan characteristics such as credit 
quality, borrowing history, and loan size at the point where firms make debt source decisions. Focusing on incremental financing decisions also allows us to separate bank loans into syndicated and bilateral loans.

Table 5 summarizes loan announcements for our sample firms between 2001 and $2013 .^{14}$ In addition to the public, bank, and non-bank private debt classification for existing loans we separate new bank loans into bilateral single lender loans and loans syndicated across a number of lending banks.

Panel A presents our initial sample of 1,365 loans over time and across debt sources. Consistent with our findings for existing debt, bank loans are the most frequent source of new debt finance announcements for our sample of UK firms. However, syndicated debt is the dominant method of raising debt capital from banks; $80 \%$ of all bank loans for our sample firms are made through a lending syndicate, which is notably higher than the 65\% in Marsh (2006) for a sample of US bank loans. We attribute this to the lesser role of publicly traded bonds as a source of finance for UK firms and syndicated bank loans providing an alternative financing source. For example, using a similar sample construction, Hadlock and James (2002) find that public bonds are issued more frequently than bank loans for their sample of US firms.

There is an increase in the use of bank debt, both syndicated and bilateral, in the lead up to the global financial crisis. Bank and public debt issuance experience a noticeable decline in frequency in 2008 and 2009 surrounding the crisis. Bank debt recovers following the crisis, but public debt issuance remains infrequent in the post-crisis period. Non-bank private debt issuance does not experience a strong change in frequency of issuance surrounding the crisis, which is consistent with the notion that non-bank debt is used for non-conventional purposes and therefore is not expected to follow general market financing trends.

\footnotetext{
${ }^{14}$ Loans are made at time $t+1$ relative to the year the firm is in the FTSE-350 index.
} 


\section{[Insert Table 5 about here]}

We combine multiple loans of the same debt type within a single financial year, which reduces the initial sample of 1,365 loans to 1,002 firm-year debt issue observations. To examine the factors impacting the discrete debt source choice we then exclude firm-years where firms borrow from more than one source during a financial year. This removes confounding debt announcements and therefore we can examine the factors impacting the discrete debt source choice for each source of debt exclusively. This reduces the sample size to 794 firm-year observations. In our empirical testing this sample falls to 629 firm-years after matching to loan characteristics, accounting and credit market data. This sample comprises 130 public debt issues, 353 syndicated bank loans, 82 bilateral bank loans, and 64 non-bank private loans. We report the distribution of these loans over time in Panel B of Table 5. In years where firms have multiple loans from a single source we include these in our sample and take the loan characteristics from the first announcement during the financial year. The final sample reported in Panel B of Table 5 displays a similar time series pattern to the data in Panel A. We find a higher attrition rate for bonds and non-bank private debt relative to bank loans due to a small number of frequent bond market issuers. ${ }^{15}$

\section{(ii) Univariate Analysis of the Choice of Incremental Debt Source}

The summary statistics for debt issuance in Table 5 highlight that the majority of our bank loans are syndicated and not the single lender bilateral type loans often implicit in theoretical models of bank monitoring. As such, we develop our empirical analysis of marginal financing choice by focusing on the choice between public debt, bilateral bank loans, syndicated bank loans, and non-bank private debt. This extends the earlier work of Denis and Mihov (2003) and allows us to

\footnotetext{
${ }^{15}$ We examine the robustness of our findings to this filter in Section 6.
} 
directly test the theoretical arguments of Dennis and Mullineaux (2000) and Sufi (2007) that syndicated loans are intermediate between bilateral bank loans and publicly traded debt. For example, the monitoring (Diamond, 1991) or renegotiating (Preece and Mullineaux, 1996) of a syndicated loan is more straightforward than for an equivalent publicly traded bond with widely dispersed lenders, but more difficult than for a single lender bilateral loan. We present univariate comparisons of firm and loan characteristics across debt sources in Table 6 for the sample of 629 loans where we are able to match to loan characteristics, accounting and credit market data.

Consistent with our previous findings and reputation arguments we find that public debt issuers are larger than other debt issuers. Bank borrowers are smaller than public issuers, irrespective of whether these are syndicated or bilateral loans. Issuers of bilateral loans are smaller than issuers of non-bank private debt. Based on fixed assets ratios, public debt issuers offer greater collateral, followed by bank borrowers, while non-bank private borrowers offer the lowest potential collateral on loans. This result supports theories of debt source based on ease of renegotiation where borrowers with little collateral opt for debt sources that can be easily restructured in the event of financial distress. Our results in Table 6 do not support the asymmetric information theory of bank debt of Hadlock and James (2002) or the credit rating explanation of Denis and Mihov (2003). We find no evidence of a relation between debt source and either firm performance or interest coverage.

[Insert Table 6 about here]

When focusing on loan characteristics we find some significant differences between bilateral and syndicated bank loans indicating the importance of examining the two types of bank loan independently. Syndicated loans are larger than all other debt issues for our sample firms but there is no significant difference in loan size between public debt and bilateral bank loans. 
Non-bank private debt issues are the smallest by a considerable margin. This result emphasizes the importance of syndicated loans for our sample firms. Syndicated borrowers are smaller than public debt issuers but they use the syndicated loan market to raise the largest amounts of finance. Our finding for loan size is not easily supported by the reputation or ease of renegotiation theories of Diamond (1991) and Preece and Mullineaux (1996). These theories do not explicitly refer to loan size, but they offer no clear explanation why bilateral bank loans and publicly traded bonds raise similar amounts of capital but syndicated loans raise the largest amounts of finance. Consistent with prior US studies, public debt has the longest maturity of all debt sources. The average loan has a maturity of 12.10 years, which is three times the 4 -year maturity of the average syndicated or bilateral bank loan. Non-bank private debt is typically issued at maturities between these two other sources. These findings are consistent with Denis and Mihov (2003) for public and non-bank private debt and Preece and Mullineaux (1996), who find that syndicated and bilateral loans have similar maturities.

Examining the link between debt source and economic and credit market conditions, we find that bilateral loans are issued more frequently during periods of weak economic growth. This is also apparent in Table 5, which highlights an increase in the use of bilateral loans from 2011. Although inconsistent with anecdotal evidence and financial press coverage surrounding the financial crisis, this could indicate that for our sample of the largest UK firms the relationships they have with their main bank lenders become important in weak economic conditions. Public debt issuance is more common when the interbank cost of funding is higher and the spread between longer dated and shorter maturity debt is lower, suggesting that firms choose shorter-term bank debt when it has a lower cost relative to public markets, and vice versa. A similar pattern is observed within bank loan choices; bilateral loans are favored over 
syndicated loans when Libor is lower and term spreads are higher, confirming the proposition that syndicated loans can act as an intermediate borrowing source between public and private debt markets. Non-bank private debt is issued during similar credit market conditions to syndicated loans.

Our sample firms also exhibit a pattern of repeat borrowing. Table 6 shows that firms issuing in public debt markets have a higher proportion of existing debt with maturity greater than one year, suggesting they optimally choose longer-term public debt to match their preferred maturity structure. Similarly, firms that are already bank dependent are more likely to continue to borrow from banks rather than from public or non-bank private sources. Only $7 \%$ of public debt issuers are classified as bank dependent; $45 \%$ of firms borrowing on a bilateral basis are classified as bank dependent, compared to $38 \%$ of syndicated borrowers. A similar pattern is observed when focusing on firms that already have public debt outstanding. These findings support reputational theories of debt source and extend the prior empirical work to consider differences between bilateral and syndicated loans. These results again suggest that syndicated loans can act as an intermediate financing step between a single lender bank loan and publicly traded bonds based on a firm's prior borrowing history.

In Table 7 we further explore the link between incremental debt issuance decisions and the presence of existing public or non-bank private debt on the firm's balance sheet. Following Denis and Mihov (2003) we categorize firms into five groups: (i) issuers with both public and non-bank private debt outstanding, (ii) issuers with public debt outstanding, but no non-bank private debt outstanding, (iii) issuers with non-bank private debt outstanding, but no public debt outstanding, (iv) issuers with neither public nor non-bank private debt outstanding, and (v) issuers with no outstanding debt. 


\section{[Insert Table 7 about here]}

Consistent with the reputation arguments of Diamond (1991), bank debt is the main debt source for firms with no debt outstanding or no public debt outstanding. Of the 156 issuing firms with no public or non-bank private debt outstanding, $136(87 \%)$ use bank loans as their marginal debt source. The majority of these involve a syndicated loan. However, amongst firms with public debt outstanding, our sample firms remain more likely to use syndicated bank debt than any other debt source. This is inconsistent with Denis and Mihov (2003) who find that firms with public debt outstanding are more likely to use public debt than any other source in their incremental financing choice.

This descriptive analysis provides further support for our univariate statistics in Table 6, which suggest an important role for syndicated bank loans for firms that could otherwise be expected to borrow in public debt markets. These results are consistent with Altunbas et al. (2009) who state that bonds and syndicated loans are used simultaneously by the largest European firms. The findings of Table 7 also suggest no obvious pattern to non-bank private debt based on prior debt sourcing decisions. This confirms that non-bank private debt is a distinct source of debt financing, and is consistent with the smaller amounts of finance raised under nonbank private loans in Table 6.

\section{(iii) Nested Logit Models for the Joint Decision of Security Type and Lender Choice}

Huang and Ritter (2009) and Gomes and Phillips (2012) note that firms endogenously choose both the security to be issued and the market to issue. Analyzing debt financing within the structure of a nested logit model assumes that independence of irrelevant alternatives (IIA) holds only within individual nests. We follow the structure of Gomes and Phillips (2012) in 
examining the choice between debt financing sources across security type and the choice of lending market. We propose two alternative structures for the nested logit model of a firm's borrowing source decision. In the first we examine the choice of lender conditional on the security type chosen and in the second case we examine the choice of security conditional on the choice of lender. In both cases the nested logit is estimated with standard errors clustered by issuing firm. All firm, loan and economic variables are as defined in Section 2 (iii).

In the first nested logit model, we assume that firms choose their preferred security between bonds (public or non-bank private) and loans (syndicated or bilateral), and conditional on the choice between bonds and loans choose to borrow in a market with dispersed lenders (public bonds or syndicated debt) or markets with concentrated lenders (non-bank private debt and bilateral loans). In this model, we allow unobserved factors to affect the market choice conditional on the security type chosen between bonds and loans (Huang and Ritter, 2009). We report the results of this nested logit in Table 8.

The results for security choice are displayed in model 1 of Table 8 . We find that bonds are favored by larger firms and by lower credit quality firms. We find evidence of a preferred maturity structure for debt, where bonds are issued for longer maturities and by firms who already have a higher proportion of long-term debt in their financing structure. Loans, on the other hand, are preferred by firms with more fixed assets. For our sample of larger firms, we find that loans are also preferred by firms raising larger amounts of financing.

[Insert Table 8 about here]

Models 2 and 3 report results for the choice of market to raise debt finance, which is conditional on the choice of security in the first model. In model 2 we find that private bonds are issued by larger firms, for smaller amounts and for shorter maturities. We find that private bonds 
are also preferred by bank dependent firms, who we expect have been screened out of public debt markets. Private bonds are also preferred over public bonds when term spreads are higher.

We find less variation in the determinants of bilateral and syndicated loans in model 3 , conditional on choosing to borrow using a bank loan in the first instance. Firms with higher earnings volatility are more likely to borrow in the syndicated loan market, which is consistent with syndicated loans being used to reduce the credit risk of individual lenders (see Dennis and Mullineaux, 2000). Conditional on the choice of bank lending, syndicated loans are likely to be preferred when Libor rates are lower.

Table 9 presents the results of our lender choice nested logit model, where firms choose between markets with dispersed and concentrated lenders in the first stage, and conditional on this choose the type of security preferred in the second stage. In the first stage model 1, we find that larger firms, firms with higher fixed assets ratios, and firms borrowing for shorter maturities choose to borrow from dispersed groups of lenders. This supports borrower reputation and ease of renegotiation theories of debt source whereby high reputation firms with more tangible assets are able to borrow from a more dispersed group of lenders. Bank dependent firms are more likely to borrow from lending sources characterized by concentrated lenders, as are firms with a higher proportion of existing long-term debt. Finally, firms are less likely to borrow from a dispersed group of lenders when Libor and term spreads are high.

[Insert Table 9 about here]

Models 2 and 3 of Table 9 report our findings for the choice of security conditional on the choice of lending market. We again find that larger firms prefer bonds over loans. Within each nest, loans are for shorter maturities but are again raised for larger amounts relative to bond financing. Non-bank private debt is preferred over bilateral loans when for firms with a higher 
proportion of existing long-term debt and when Libor rates are higher. Finally, syndicated loans are preferred to public bonds for bank dependent firms and when Libor is higher. This supports the theory that bank dependent firms are less likely to be able to access public debt markets, which could suggest a hold-up problem where bank dependent firms are restricted to current lenders for future finance (Rajan, 1992; Houston and James, 1996). ${ }^{16}$ This provides some evidence that syndicated loans may act as an intermediate source of finance for firms seeking an alternative to the public bond market to raise larger amounts of debt financing. ${ }^{17,18}$

Overall, our findings support the theory that a firm's past financing choice affects future financing decisions (Diamond, 1991). We find that bank dependent firms are significantly less likely to borrow in public debt markets, but bank dependency has little impact on the choice amongst bilateral, syndicated, and non-bank private debt. Firms with large amounts of existing bank debt are screened out of public debt markets, which could suggest a hold-up problem where bank dependent firms are restricted to current lenders for future finance (Rajan, 1992; Houston and James, 1996). ${ }^{19,20}$

\footnotetext{
${ }^{16}$ Rajan (1992) argues that continued relations with one bank could result in a "lock-in effect". Banks can extract high rents because they acquire monopoly power with respect to private information about the borrowing firm, leading to both monopolistic borrowing rates and expensive switching costs.

${ }^{17}$ To further examine the effect of multicollinearity amongst our explanatory variables in this section, we check VIFs. This highlighted multicollinearity concerns between Libor and $\triangle G D P$ and between the Bank dependent and the Public debt outstanding dummy variables, which led us to drop $\triangle G D P$ and Public debt outstanding in the multivariate analysis. The remaining VIFs are below 10 for all our variables, which is within the acceptable range discussed by Gujarati (2003).

${ }^{18}$ The McFadden pseudo-R squared values reported in Tables 8 and 9 are noticeably higher than the equivalent values reported by Denis and Mihov (2003). This is driven by the inclusion of loan maturity as an explanatory variable in our regressions. If we exclude loan maturity from out regressions the $\mathrm{R}$ squared values are almost identical to those reported by Denis and Mihov. We choose to include loan maturity because our univariate analysis shows that it is highly correlated with debt source. Moreover, we also check for multicolinearity in this subsequent testing to ensure that maturity does not interact with other firm characteristics to lead to spurious regression coefficients and we find that the VIF for loan maturity is 1.16 , which is again within the acceptable range discussed by Gujarati (2003).

${ }^{19}$ In unreported testing we replace Bank dependent with the Public debt outstanding dummy variable described in Section 2 (iii). We again find that firms with existing public debt are more likely to borrow from public debt markets. The coefficients of public debt, syndicated bank loans, and non-bank private debt are statistically insignificant from one another, suggesting that firms with existing public debt outstanding choose amongst these
} 


\section{THE IMPACT OF THE GLOBAL FINANCIAL CRISIS ON BORROWING SOURCE}

Our sample time period overlaps with an increase in the difficulty for even the largest firms to obtain credit as a result of the global financial crisis that began in late 2007, which could bias our analysis of the factors that determine debt source. In this section, we re-estimate our key findings to examine the impact of the crisis on the determinants of a firm's reported balance sheet debt source mix and marginal debt financing choice.

We split the sample into pre- and post-crisis periods for firm years 2000 to 2007 and 2008 to 2012 and re-estimate our core findings. In Table 10 we re-estimate our analysis of existing debt source from Table 4. Panel A reports the results for the pre-crisis period, and Panel B for the post-crisis period. We find that splitting the sample into pre- and post-crisis periods does affect several determinants of existing debt source. We find that the impact of firm size on debt source is consistent across both time periods, although the positive relation between size and non-bank private debt use is insignificant in the post-crisis period. The apparently anomalous positive impact of earnings volatility on public debt use is confined to the pre-crisis period. We find no relation between earnings volatility and debt sourcing in the post-crisis period.

[Insert Table 10 about here]

In the post-crisis period firm age is positively related to public debt use and negatively related to bank debt. This is consistent with Johnson (1997) and supports Diamond's (1991) reputation theory of debt source where only the most reputable firms can access public debt markets. The reputation theory is also supported by a positive relation between profitability and

sources based on other firm and loan characteristics, such as maturity, firm size, loan size, and the ability to provide collateral.

20 The general conclusions from this section are largely unchanged when we examine the choice of borrowing source using a multinominal logit regression, used in the studies by Denis and Mihov (2003) and Arena (2011). 
public debt use, and a negative relation between profitability and non-bank private debt use in the post-crisis period. ${ }^{21}$

We also re-estimate our nested logit regressions of marginal borrowing source from Tables 8 and 9 separately for pre- and post-crisis time periods. In general, our findings for the role of firm and loan characteristics as determinants of borrowing source are typically stronger post-crisis. For Table 8, we find that pre-crisis firms are more likely to choose loan over bond markets where they have high leverage and borrow for shorter maturities. The choice amongst non-bank private debt and public bonds is unrelated to the firm, credit market, and loan variables that we consider in this study. Bilateral loans are preferred to syndicated loans for smaller, younger, less profitable, and weaker credit quality firms borrowing relatively larger amounts and over shorter maturities. During the pre-crisis period, the choice of bilateral loans relative to syndicated loans is negatively related to term spreads and Libor.

Post-crisis we find that loans are preferred again for larger borrowing amounts over shorter maturities. We also find weak evidence that firm size, profitability, investment opportunities, and earnings volatility influence the choice between bond and loan market borrowing. In second stage regression of the choice between concentrated and dispersed lenders we find that a number of firm characteristics are related to borrowing source choice in a manner that indicates lenders placing a greater emphasis on borrowing firm creditworthiness in their lending decisions. In all regression models we find that loans and borrowing from a concentrated number of lenders is preferred by bank dependent firms, which is consistent with Diamond's

\footnotetext{
${ }^{21}$ We also re-estimate our regression results and replace year dummies with a Financial crisis dummy set equal to one for all firm-years from 2008 onwards, and zero otherwise. We find that the crisis dummy variable is unrelated to debt source and has little impact on the remaining coefficients so as to impact our overall conclusions on the determinants of existing debt source. Thus, the financial crisis itself did not have a significant effect on the accumulated proportion of debt borrowed from individual borrowing sources. We do not report the results of this test for brevity but the findings are available on request.
} 
(1991) reputational theory of a firm's borrowing history. The importance of a firm's dependence on bank debt as an existing source of borrowing in the post-crisis time period points towards lenders placing a greater emphasis on a borrowing firm's credit history and reputation in deciding whom to lend to.

We find similar evidence when we re-estimate Table 9 for pre- and post-crisis time periods, although firm characteristics are less important when examining security choice conditional on the number of lenders in first stage regressions. Larger firms prefer to borrow from dispersed lenders and prefer bonds over loans and this relation holds over both time periods. We again find that firms classified as bank dependent are more likely to borrow in loan markets over both time periods, but conditional on loan market borrowing bank dependency affects borrowing security choice only in the post-crisis time period. This again suggests that lenders tightened their credit screening process in the post-crisis period relative to the period of credit expansion prior to 2008 .

Collectively, our analysis of debt sourcing surrounding the global financial crisis supports the basic tenants of Diamond's (1991) reputation theory of debt sourcing. We find that firm size, firm age is an important predictor of debt source in the post-crisis period when credit was most rationed and when borrower reputation was likely to matter most to lenders. Moreover, existing dependency on bank debt is unrelated to borrowing source in the pre-crisis period when lenders placed less emphasis on borrower reputation in their lending decisions during the period of credit expansion. Post-crisis we find that bank dependent firms are more likely to borrow in loan markets, and conditional on lender and security issuance choice are screened out of public bond markets. 


\section{FURTHER ANALYSIS}

This section extends our main analysis to consider a number of robustness tests to our main testing procedures and our results. ${ }^{22}$ First, when analyzing incremental financing decisions we focus on firms borrowing from a single source during the financial year. This allows us to isolate discrete debt choices but leads to a number of observations being dropped from our initial sample. Table 5 highlights that filtering for overlapping debt issuance results in a disproportionate loss of public bonds and non-bank private debt issues. To address concerns of selection bias caused by these exclusions, we re-estimate our nested logit regressions and include firm-years where firms borrow from more than one source. We find the sequence of loan announcements over time, and across alternative sources, closely tracks the figures reported in Table 5 for the full and the filtered sample, confirming that our initial decision to exclude overlapping issuers does not alter the general pattern of loan announcements over our sample period relative to the population of loan issuance by our sample. When we repeat the regression analysis of marginal financing source determinants from Tables 8 and 9 we find again that firm size and existing debt source are the key drivers of debt source in marginal financing decisions. Larger firms are more likely to borrow from public and non-bank private debt sources and firms with a higher proportion of long-term debt in their existing borrowings are less likely to borrow using syndicated and bilateral bank loans. Bank dependent firms remain less likely to borrow in public debt markets.

Second, Diamond (1991) suggests that financially distressed firms are more likely to borrow from non-traditional sources of finance. Including financially distressed firms could bias our results and suggest a greater importance for non-bank private debt than is typical for a population of financially healthy firms. Therefore, we examine the sensitivity of our regressions

\footnotetext{
${ }^{22}$ The results of this section are not tabulated for brevity but are available on request.
} 
in Tables 4,8 and 9 by excluding financially distressed firms to consider whether our findings are driven by the unique borrowing preferences of distressed firms. The negative impact of investment on public debt sourcing from Table 4 is now insignificant, but otherwise we see no significant difference in our analysis of existing debt source. Excluding financially distressed firm-years from Tables 8 and 9 has no impact on the coefficients for firm, loan and economic characteristics on marginal borrowing source. Bank dependent borrowers remain more likely to borrow from concentrated lenders and are less likely to borrow in public bond markets relative to syndicated loans. However, excluding financially distressed firms leads to the Bank dependent variable becoming insignificant in the remaining regressions. This suggests that existing financing relationships matter most for potentially constrained firms who would otherwise have difficulty in accessing external financing.

Third, when analyzing incremental financing decisions we examine each loan in isolation, without considering the financing choices of individual companies in prior years. We partly address this in Tables 8 and 9 where we examine cumulative past financing decisions on the firm's balance sheet and their impact on incremental financing choices. However, it is possible that firms' more recent borrowing decisions from different sources could influence the choice of future financing sources. To examine this issue we re-estimate our multinomial logit regressions from Tables 8 and 9 including dummy variables that capture whether firms borrowed from public, syndicated or bilateral bank or non-bank private debt sources in the previous year. Each dummy variable is set equal to one if the firm raised debt from the relevant borrowing source in the previous financial year, and zero otherwise. Including these additional lags reduces the sample size from 629 to 599 debt transactions. We find that firms issuing a public bond in the previous year are more likely to do so in the current year relative to all borrowing sources. The 
strength of the Bank dependent variable from Tables 8 and 9 in the main paper is again weakened, suggesting recent financing decisions are important to understand a firm's marginal borrowing source choice, and potentially more so than the accumulation of past borrowing decisions measured by our bank dependency variable. Otherwise, there is little evidence that the debt source in the last year impacts our core results.

Fourth, Diamond (1984) argues that banks have information advantages over other lenders. It is possible that because of the superior information that banks have there could be a difference between large loans made by banks and large loans from public sources. To address this concern, we estimate logit regressions of the likelihood of issuing a large publicly traded bond relative to a large bank loan, and against the likelihood of issuing a large syndicated loan for our sample firms. A large loan is defined as a loan that is larger than the median loan size of both public and bank loans. The results are generally mixed with respect to our core results in Tables 8 and 9. Consistent with Diamond's (1991) reputation theory, we again find that larger and more profitable firms are more likely to issue public debt. Firms with higher investment spending and weaker interest coverage are more likely to borrow from public debt sources, which contradicts life cycle and reputation based theories, but is consistent with a supply explanation where banks are unwilling to provide very large loans to risky firms with large investment requirements. After controlling for other factors, larger and shorter maturity loans are raised through banks. We find no relation between existing debt source and the likelihood of issuing public relative to bank debt. While initially contrary to our earlier findings, this evidence suggests that firms raising the largest amounts of financing are not constrained by their existing borrowing source. 
Finally, our results in Tables 2 and 4 are based on pooled firm-year observations and could be subject to endogeneity or serial correlation problems that are not remedied by the instrumental variable procedure for existing leverage or the inclusion of year dummies. To address this concern, we re-estimate our results using debt source data for 2003 and relate this to firm characteristics that are three year averages estimated from 2000 to 2002. Johnson (1997) argues that taking average values for independent variables and lagging these prior to the dependent variable removes extreme values and mitigates simultaneity concerns in his analysis of existing balance sheet debt. ${ }^{23}$ Our core results for firm size are unchanged and we again find that the proportion of bank debt is increasing with the fixed assets ratio, although the negative coefficient for non-bank private debt becomes marginally insignificant. Earnings volatility is positively related to the use of long term non-bank private debt and negatively related to long term bank debt. Although consistent with our analysis of marginal financing decisions, we find no relation between public debt use and earnings volatility. These findings strengthen our core result on the importance of firm size and collateral as determinants of existing debt source.

\section{SUMMARY AND CONCLUSIONS}

In this study we examine the choice of debt source for a sample of large non-financial UK firms over the period 2000 to 2012. We study the determinants of existing debt source and the choice of debt source for incremental financing decisions. We distinguish between existing public debt, bank debt and non-bank private debt, and between bilateral and syndicated banks loans. This allows us to simultaneously examine a broader range of debt financing sources than previously considered in the empirical research in this area. We use this classification to investigate

\footnotetext{
${ }^{23}$ We do not report these findings in our core analysis following Christie et al. (1984), who are critical of orthogonalization to control for endogeneity since the regression itself partials out the effects of other variables.
} 
Diamond's (1991) reputation based theory of debt source choice where firms with difficult to monitor assets and who naturally generate less information for investors are screened out of public debt markets.

Our findings provide support for Diamond's (1991) theory of debt source choice. Smaller firms and firms with fewer tangible assets are screened out of public debt markets. We provide mixed evidence on whether syndicated bank loans act as an intermediate step between bilateral bank loans and publicly traded bonds within the context of a wider range of financing choices (Dennis and Mullineaux, 2000; Sufi, 2007). This effect is present prior to the global financial crisis, but is not present post-2008. Moreover, syndicated loans also allow firms to raise larger amounts of financing than publicly traded debt, which does not fit easily within borrower reputation or liquidation efficiency theories of debt source choice. Our findings on the importance of fixed assets as collateral support theories of debt source based on liquidation efficiency where firms with more difficult to value intangible assets are more likely to choose private debt sources.

Our findings raise a number of important issues for future research. The fact that we find little role for financial distress and credit risk suggests these are unimportant for borrowing decisions by UK firms, that our proxies are imperfect or that credit risk is less important when analyzing a sample of large firms. We chose FTSE-350 firms in this study to ensure availability of loan announcement data and to focus on firms that are more likely to have a range of choice of debt source. It is possible that credit risk is more important in determining debt source choice between large and small firms.

More generally, our findings on non-bank private debt and bilateral and syndicated loans highlight the importance of considering a broader range of financing choices in corporate finance 
research. The broad heading of non-bank private debt covers a range of discrete debt sources that are worthy of further investigation. These include direct loans from institutional investors and private bonds. Further detailed analysis of debt classified under this heading will require a longer time frame and broader range of sample firms. 


\section{REFERENCES}

Agarwal, V. and R. Taffler, 2008, Comparing the performance of market-based and accountingbased bankruptcy prediction models, Journal of Banking and Finance, Vol. 32, 1,541-1,551.

Altunbas, Y., A. Kara and D. Ibanez, 2009, Large debt financing: syndicated loans versus corporate bonds, European Central Bank, Working Paper No. 1028.

Antoniou, A., Y. Guney and K. Paudyal, 2008, The determinants of corporate debt ownership structure: evidence from market-based and bank-based economies, Managerial Finance, Vol. $34,821-847$.

Arena, M. P., 2011, The corporate choice between public debt, bank loans, traditional private debt placements, and 144A debt issues, Review of Quantitative Finance and Accounting, Vol. 36, 391-416.

Ball, R., R. M. Bushman and F. P. Vasvari, 2008, The debt-contracting value of accounting information and loan syndicate structure, Journal of Accounting Research, Vol. 46, 247-288.

Bank of England, 2009, Trends in lending, August 2009, http://www.bankofengland.co.uk/publications/other/monetary/TrendsAugust09.pdf.

Bank of England, 2012, Trends in lending, October 2012, http://www.bankofengland.co.uk/publications/other/monetary/TrendsOctober12.pdf.

Barclay, M. J. and C. W. Smith, 1995, The maturity structure of corporate debt, Journal of Finance, Vol. 50, 609-631.

Barnes, E. and B. Cahill, 2005, Private or public debt? Drivers of debt priority structure for UK firms, Irish Accounting Review, Vol. 12, 1-13.

Blackwell, D. W. and D. S. Kidwell, 1988, An investigation of cost differences between public sales and private placements of debt, Journal of Financial Economics, Vol. 22, 253-278.

Boot, A. W. A., 2000, Relationship banking: what do we know?, Journal of Financial Intermediation, Vol. 9, 7-25.

Breedon, T., 2012, Boosting finance options for business, London: Department for Business Innovation and Skills.

Bushman, R. M., A. J. Smith and R. Wittenberg-Moerman, 2010, Price discovery and dissemination of private information by loan syndicate participants, Journal of Accounting Research, Vol. 48, 921-972.

Bushman, R. M. and R. Wittenberg-Moerman, 2012, The role of bank reputation in "certifying" future performance implications of borrowers' accounting numbers, Journal of Accounting Research, Vol. 50, 883-930.

Cantillo, M. and J. Wright, 2000, How do firms choose their lenders? An empirical investigation, Review of Financial Studies, Vol. 13, 155-189.

Carey, M., M. Post and S. A. Sharpe, 1998, Does corporate lending by banks and finance companies differ? Evidence on specialization in private debt contracting, Journal of Finance, Vol. 53, 845-878.

Carey, M., S. Prowse, J. Rea and G. F. Udell, 1993, The economics of private placements: A new look, Financial Markets, Institutions, and Instruments, Vol. 2, 1-67.

Chandra, U. and N. Nayar, 2008, The information content of private debt placements, Journal of Business Finance and Accounting, Vol. 35, 1,164-1,195.

Chemmanur, T. J. and P. Fulghieri, 1994, Reputation, renegotiation, and the choice between bank loans and publicly traded debt, Review of Financial Studies, Vol. 7, 673-692. 
Christie, A. A., M. D. Kennelley, J. W. King and T. F. Schaefer, 1984, Testing for incremental information content in the presence of collinearity, Journal of Accounting and Economics, Vol. 6, 205-217.

Clubb, C. and G. $\mathrm{Wu}, 2014$, Earnings volatility and earnings prediction: analysis and UK evidence, Journal of Business Finance and Accounting, Vol. 41, 53-72.

Dang, V. A., 2011, Leverage, debt maturity and firm investment: An empirical analysis, Journal of Business Finance and Accounting, Vol. 38, 225-258.

Denis, D. J. and V. T. Mihov, 2003, The choice among bank debt, non-bank private debt and public debt: evidence from new corporate borrowings, Journal of Financial Economics, Vol. 70, 3-28.

Dennis, S. A. and D. J Mullineaux, 2000, Syndicated loans, Journal of Financial Intermediation, Vol. 9, 404-426.

Diamond, D. W., 1984, Financial intermediation and delegated monitoring, Review of Financial Economics, Vol. 51, 393-414.

Diamond, D. W., 1991, Monitoring and reputation: The choice between bank loans and directly placed debt, Journal of Political Economy, Vol. 99, 689-721.

Diamond, D. W., 1993, Seniority and maturity of debt contracts, Journal of Financial Economics, Vol. 33, 341-368.

Drucker, S. and M. Puri, 2009, On loan sales, loan contracting, and lending relationships, Review of Financial Studies, Vol. 22, 2,835-2,872.

Fama, E. F., 1985, What's different about banks?, Journal of Monetary Economics, Vol. 15, 2939.

Faulkender, M. and M. A. Petersen, 2006, Does the source of capital affect capital structure?, Review of Financial Studies, Vol. 19, 45-79.

Godlewski, C. J., B. Sanditov and T. Burger-Helmchen, 2012, Bank lending networks, experience, reputation, and borrowing costs: Empirical evidence from the French syndicated lending market, Journal of Business Finance and Accounting, Vol. 39, 113-140.

Gomes, A. and G. Phillips, 2012, Why do public firms issue private and public securities?, Journal of Financial Intermediation, Vol. 21, 619-659.

Gujarati, D. N., 2003, Basic Econometrics (New York: McGraw-Hill).

Hadlock, C. J. and C. M. James, 2002, Do banks provide financial slack?, Journal of Finance, Vol. 57, 1,383-1,419.

Houston, J. and C. M. James, 1996, Bank information monopolies and the mix of private and public debt claims, Journal of Finance, Vol. 51, 1,863-1,889.

Hovakimian, G. and S. Titman, 2004, Corporate investment and financial constraints: Sensitivity of investment to funds from voluntary asset sales, Journal of Money, Credit, and Banking, Vol. 38, 357-374.

Huang, R. and J. R. Ritter, 2009, Testing theories of capital structure and estimating the speed of adjustment, Journal of Financial and Quantitative Analysis, Vol. 44, 237-271.

James, C. M., 1987, Some evidence on the uniqueness of bank loans, Journal of Financial Economics, Vol. 19, 217-235.

Johnson, S. A., 1997, An empirical analysis of the determinants of corporate debt ownership structure, Journal of Financial and Quantitative Analysis, Vol. 32, 47-69.

Johnson, S. A., 1998, The effect of bank debt on optimal capital structure, Financial Management, Vol. 27, 47-56. 
Krishnaswami, S., P. A. Spindt and V. Subramaniam, 1999, Information asymmetry, monitoring, and the placement structure of corporate debt, Journal of Financial Economics, Vol. 51, 407434.

Kwan, S. H. and W. T. Carleton, 2010, Financial contracting and the choice between private placement and publicly offered bonds, Journal of Money, Credit and Banking, Vol. 42, 907929.

Marsh, I. M., 2006, The effect of lenders' credit transfer activities on borrowing firms' equity returns, Bank of Finland Discussion Paper 31.

Maskara, P. K. and D. J. Mullineaux, 2011, Information asymmetry and self-selection bias in bank loan announcement studies, Journal of Financial Economics, Vol. 101, 684-694.

Myers, S. C., 1984, The capital structure puzzle, Journal of Finance, Vol. 39, 575-592.

Opler, T., L. Pinkowitz, R. Stulz and R. Williamson, 1999, The determinants and implications of corporate cash holdings, Journal of Financial Economics, Vol. 52, 3-46.

Preece, D., and D. J. Mullineaux, 1996, Monitoring, loan re-negotiability, and firm value: the role of lending syndicates, Journal of Banking and Finance, Vol. 20, 577-593.

Rajan, R. G., 1992, Insiders and outsiders: The choice between informed and arm's-length debt, Journal of Finance, Vol. 47, 1, 367-400.

Rajan, R. G. and L. Zingales, 1995, What do we know about capital structure? Some evidence from international data, Journal of Finance, Vol. 50, 421-1,460.

Sufi, A., 2007, Information asymmetry and financing arrangements: Evidence from syndicated loans, Journal of Finance, Vol. 17, 629-668.

Yosha, O., 1995, Information disclosure costs and the choice of financing source, Journal of Financial Intermediation, Vol. 4, 3-20. 


\section{Table 1}

\section{Descriptive statistics for sample firms}

This table presents selected summary statistics for a sample of 400 firms listed in the FTSE-350 index of the London Stock Exchange (LSE) between 2000 and 2012. The sample is constructed by including all firms listed in the FTSE350 , excluding financials and utilities, during the period 2000-2012 for the years that they were listed in the FTSE350. Firm size is measured as the book value of total assets (£millions) deflated to 2000 sterling figures using the UK consumer price inflation index. Firm age is measured from the date of incorporation. Fixed assets ratio is defined as the ratio of plant, property, and equipment to total assets. Specialized industry is a dummy variable which takes the value of one for firms with SIC code between 3400 and 3999, and zero otherwise. Investment is defined as the sum of capital expenditures and research and development spending divided by total assets. Earnings volatility is defined as the standard deviation of pretax income minus incomes taxes for the previous three years divided by the average total assets for the period. Return on assets is measured as the ratio of earnings before interest, tax, depreciation and amortization to total assets. Interest coverage is calculated as EBITDA divided by total interest payable. Leverage is measured as the book value of total debt divided by the book value of total assets. All debt ratio figures are based on book values. Long-term debt is defined as debt with a maturity greater than one year.

\begin{tabular}{|c|c|c|c|c|c|c|}
\hline & Mean & Median & Max & Min & Std Dev & $\begin{array}{c}\text { No of } \\
\text { observations }\end{array}$ \\
\hline Firm size & 3,500 & 1,100 & 170,000 & 5.30 & 10,611 & 2529 \\
\hline Firm age & 42.35 & 27.00 & 164.00 & 1.00 & 36.83 & 2337 \\
\hline Fixed assets ratio & 0.29 & 0.21 & 0.98 & 0.00 & 0.24 & 2520 \\
\hline Specialized industry & 0.16 & & & & & 2563 \\
\hline Investment & 0.06 & 0.05 & 0.98 & 0.00 & 0.07 & 2527 \\
\hline Earnings volatility & 0.04 & 0.02 & 1.45 & 0.00 & 0.07 & 2468 \\
\hline Return on assets & 0.13 & 0.13 & 1.05 & -1.80 & 0.12 & 2528 \\
\hline Leverage & 0.30 & 0.23 & 68.85 & 0.00 & 1.48 & 2529 \\
\hline Interest coverage & 30.76 & 8.31 & $16,514.33$ & -454.80 & 344.96 & 2559 \\
\hline Public debt to total debt & 0.24 & 0.00 & 1.00 & 0.00 & 0.35 & 2563 \\
\hline Bank debt to total debt & 0.60 & 0.71 & 1.00 & 0.00 & 0.40 & 2563 \\
\hline Non-bank private debt to total debt & 0.15 & 0.00 & 1.00 & 0.00 & 0.29 & 2563 \\
\hline $\begin{array}{l}\text { Long-term public debt to total } \\
\text { long-term debt }\end{array}$ & 0.28 & 0.00 & 1.00 & 0.00 & 0.39 & 2343 \\
\hline $\begin{array}{l}\text { Long-term bank debt to total long- } \\
\text { term debt }\end{array}$ & 0.54 & 0.56 & 1.00 & 0.00 & 0.43 & 2343 \\
\hline $\begin{array}{l}\text { Long-term non-bank private debt to } \\
\text { total long-term debt }\end{array}$ & 0.18 & 0.00 & 1.00 & 0.00 & 0.33 & 2343 \\
\hline $\begin{array}{l}\text { Fraction of firms with any public } \\
\text { debt outstanding }\end{array}$ & 0.42 & & & & & 2563 \\
\hline $\begin{array}{l}\text { Fraction of firms with any bank } \\
\text { debt outstanding }\end{array}$ & 0.95 & & & & & 2563 \\
\hline $\begin{array}{l}\text { Fraction of firms with any non- } \\
\text { bank private debt outstanding }\end{array}$ & 0.43 & & & & & 2563 \\
\hline
\end{tabular}


Table 2

Univariate comparison of sample firms by main borrowing source

This table presents mean (median) comparisons of firm variables for a sample of 400 firms listed in the FTSE-350 index of the London Stock Exchange (LSE) between 2000 and 2012. Sample construction and variable definitions are provided in Table 1. Firm years are allocated to sub groups according to the largest proportion of their reported total debt outstanding in that year: "mostly public", "mostly bank" and "mostly non-bank private." Superscripts 1,2 , and 3 denote that firm characteristics for firms borrowing predominantly from one debt source are significantly different at the 5\% level or greater from those borrowing predominantly from the borrowing source in the corresponding numbered columns. The significance of the difference in means is determined using a t-test of means. The significance of the differences in medians is determined in using the Kruskal-Wallis Test, and the significance of the differences in proportions is determined using the Wilcoxon Rank Sum Test.

\begin{tabular}{|c|c|c|c|}
\hline & $\begin{array}{l}\text { Firms with mostly public } \\
\text { debt outstanding } \\
(\mathrm{N}=614)\end{array}$ & $\begin{array}{l}\text { Firms with mostly bank } \\
\text { debt outstanding } \\
(\mathrm{N}=1284)\end{array}$ & $\begin{array}{c}\text { Firms with mostly non- } \\
\text { bank private debt } \\
\text { outstanding } \\
(\mathrm{N}=350)\end{array}$ \\
\hline & (1) & (2) & (3) \\
\hline \multirow[t]{2}{*}{ Firm size } & $6,973^{2}$ & $1,336^{1,3}$ & $4,823^{2}$ \\
\hline & $(2,950)^{2,3}$ & $(640)^{1,3}$ & $(1,350)^{1,2}$ \\
\hline \multirow{2}{*}{ Firm age } & $49.88^{2}$ & $39.18^{1,3}$ & $45.03^{2}$ \\
\hline & $(32.00)^{2,3}$ & $(25.00)^{1,3}$ & $(37.50)^{1,2}$ \\
\hline \multirow{2}{*}{ Fixed assets ratio } & $0.31^{3}$ & $0.29^{3}$ & $0.24^{1,2}$ \\
\hline & $(0.22)^{2,3}$ & $(0.21)^{1,3}$ & $(0.19)^{1,2}$ \\
\hline Specialized industry & $0.13^{2}$ & $0.17^{1}$ & 0.17 \\
\hline \multirow[t]{2}{*}{ Investment } & $0.06^{2}$ & $0.07^{1}$ & 0.06 \\
\hline & $(0.05)$ & $(0.05)$ & $(0.05)$ \\
\hline \multirow[t]{2}{*}{ Earnings volatility } & 0.04 & 0.04 & 0.04 \\
\hline & $(0.02)^{2}$ & $(0.02)^{1,3}$ & $(0.02)^{2}$ \\
\hline \multirow[t]{2}{*}{ Return on Assets } & $0.13^{2}$ & $0.14^{1,3}$ & $0.12^{2}$ \\
\hline & $(0.13)^{2}$ & $(0.14)^{1,3}$ & $(0.12)^{2}$ \\
\hline \multirow[t]{2}{*}{ Leverage } & $0.30^{2}$ & $0.22^{1,3}$ & $0.27^{2}$ \\
\hline & $(0.28)^{2,3}$ & $(0.20)^{1}$ & $(0.21)^{1}$ \\
\hline
\end{tabular}


Table 3

Pairwise correlations of explanatory variables for existing debt source determinants

This table presents the correlation matrix of selected variables of existing debt source for a sample of 400 firms listed in the FTSE-350 index of the London Stock Exchange (LSE) between 2000 and 2012. Sample construction and variable definitions are provided in Table 1. P-values are reported in parenthesis.

\begin{tabular}{|c|c|c|c|c|c|c|c|}
\hline & $\begin{array}{l}\text { Ln (Firm } \\
\text { size) } \\
\end{array}$ & $\begin{array}{l}\text { Ln (Firm } \\
\text { age) }\end{array}$ & $\begin{array}{c}\text { Fixed assets } \\
\text { ratio }\end{array}$ & $\begin{array}{c}\text { Specialized } \\
\text { industry }\end{array}$ & Investment & $\begin{array}{l}\text { Earnings } \\
\text { volatility }\end{array}$ & $\begin{array}{c}\text { Return on } \\
\text { assets }\end{array}$ \\
\hline $\begin{array}{l}\text { Ln (Firm } \\
\text { age) }\end{array}$ & $\begin{array}{c}0.1344 * * * \\
(0.000)\end{array}$ & & & & & & \\
\hline $\begin{array}{l}\text { Fixed assets } \\
\text { ratio }\end{array}$ & $\begin{array}{c}0.0844 * * * \\
(0.000)\end{array}$ & $\begin{array}{l}0.0214 \\
(0.306)\end{array}$ & & & & & \\
\hline $\begin{array}{l}\text { Specialized } \\
\text { industry }\end{array}$ & $\begin{array}{c}-0.1088 * * * \\
(0.000)\end{array}$ & $\begin{array}{c}0.1865 * * * \\
(0.000)\end{array}$ & $\begin{array}{c}-0.1560 * * * \\
(0.000)\end{array}$ & & & & \\
\hline Investment & $\begin{array}{c}-0.1485 * * * \\
(0.000)\end{array}$ & $\begin{array}{c}-0.1385 * * * \\
(0.000)\end{array}$ & $\begin{array}{c}0.3269 * * * \\
(0.000)\end{array}$ & $\begin{array}{c}0.0731 * * * \\
(0.000)\end{array}$ & & & \\
\hline $\begin{array}{l}\text { Earnings } \\
\text { volatility }\end{array}$ & $\begin{array}{c}-0.1520 * * * \\
(0.000)\end{array}$ & $\begin{array}{c}-0.0661 * * * \\
(0.002)\end{array}$ & $\begin{array}{c}-0.0989 * * * \\
(0.000)\end{array}$ & $\begin{array}{r}-0.0017 \\
(0.932)\end{array}$ & $\begin{array}{c}0.1054 * * * \\
(0.000)\end{array}$ & & \\
\hline $\begin{array}{l}\text { Return on } \\
\text { assets }\end{array}$ & $\begin{array}{c}-0.1196 * * * \\
(0.000)\end{array}$ & $\begin{array}{c}-0.0522 * * \\
(0.012)\end{array}$ & $\begin{array}{c}0.0697 * * * \\
(0.001)\end{array}$ & $\begin{array}{l}0.0011 \\
(0.956)\end{array}$ & $\begin{array}{c}0.1398 * * * \\
(0.000)\end{array}$ & $\begin{array}{c}-0.2352 * * * \\
(0.000)\end{array}$ & \\
\hline Leverage & $\begin{array}{r}-0.0283 \\
(0.156) \\
\end{array}$ & $\begin{array}{c}0.0448 * * \\
(0.032) \\
\end{array}$ & $\begin{array}{r}-0.0101 \\
(0.612) \\
\end{array}$ & $\begin{array}{r}-0.0199 \\
(0.318) \\
\end{array}$ & $\begin{array}{r}-0.0213 \\
(0.285) \\
\end{array}$ & $\begin{array}{r}-0.0105 \\
(0.604) \\
\end{array}$ & $\begin{array}{c}-0.0174 \\
(0.383) \\
\end{array}$ \\
\hline
\end{tabular}


Table 4

Determinants of balance sheet debt source

This table presents the results of second stage instrumental variable Tobit regressions of debt source for a sample of 400 firms listed in the FTSE-350 index of the London Stock Exchange (LSE) between 2000 and 2012 . Sample construction and variable definitions are provided in Table 1. The dependent variable is censored between zero and one. The unreported first stage regression of the determinants of leverage and long-term leverage use cash divided by total assets as the instrumental variable. Year dummy variables are included in the regressions but are not reported for brevity. P-values derived from standard errors clustered at the firm level are reported in parentheses. $* * *, * *$, and $*$ denote the parameters are significant at the $1 \%, 5 \%$, and $10 \%$ levels respectively.

\begin{tabular}{|c|c|c|c|c|c|c|}
\hline & $\begin{array}{l}\text { Public debt } \\
\text { to total debt }\end{array}$ & $\begin{array}{c}\text { Bank debt to } \\
\text { total debt }\end{array}$ & $\begin{array}{l}\text { Non-bank } \\
\text { private debt } \\
\text { to total debt }\end{array}$ & $\begin{array}{l}\text { Long-term } \\
\text { public debt } \\
\text { to total } \\
\text { long-term } \\
\text { debt }\end{array}$ & $\begin{array}{l}\text { Long-term } \\
\text { bank debt to } \\
\text { total long- } \\
\text { term debt }\end{array}$ & $\begin{array}{l}\text { Long-term } \\
\text { non-bank } \\
\text { private debt } \\
\text { to total } \\
\text { long-term } \\
\text { debt }\end{array}$ \\
\hline & (1) & (2) & (3) & (4) & (5) & (6) \\
\hline Intercept & $\begin{array}{c}-6.4140 * * * \\
(0.000)\end{array}$ & $\begin{array}{c}5.4519 * * * \\
(0.000)\end{array}$ & $\begin{array}{c}-1.8922 * * * \\
(0.000)\end{array}$ & $\begin{array}{c}-8.7610 * * * \\
(0.000)\end{array}$ & $\begin{array}{c}6.2259 * * * \\
(0.000)\end{array}$ & $\begin{array}{c}-1.4694 \\
(0.143)\end{array}$ \\
\hline Ln (Firm size) & $\begin{array}{c}0.2923 * * * \\
(0.000)\end{array}$ & $\begin{array}{c}-0.2439 * * * \\
(0.000)\end{array}$ & $\begin{array}{c}0.0958 * * * \\
(0.001)\end{array}$ & $\begin{array}{c}0.3924 * * * \\
(0.000)\end{array}$ & $\begin{array}{c}-0.3077 * * * \\
(0.000)\end{array}$ & $\begin{array}{c}0.0907 * * \\
(0.043)\end{array}$ \\
\hline Ln (Firm age) & $\begin{array}{l}0.0464 \\
(0.108)\end{array}$ & $\begin{array}{c}-0.0438 \\
(0.254)\end{array}$ & $\begin{array}{l}0.0231 \\
(0.493)\end{array}$ & $\begin{array}{c}0.0759 * \\
(0.069)\end{array}$ & $\begin{array}{c}-0.0383 \\
(0.597)\end{array}$ & $\begin{array}{l}0.0013 \\
(0.984)\end{array}$ \\
\hline Fixed assets ratio & $\begin{array}{c}0.3255 \\
(0.166)\end{array}$ & $\begin{array}{c}-0.2829 \\
(0.286)\end{array}$ & $\begin{array}{c}0.0020 \\
(0.993)\end{array}$ & $\begin{array}{c}0.4799 \\
(0.235)\end{array}$ & $\begin{array}{c}-0.7967 \\
(0.179)\end{array}$ & $\begin{array}{l}0.3220 \\
(0.497)\end{array}$ \\
\hline Specialized industry & $\begin{array}{l}-0.0445 \\
(0.702)\end{array}$ & $\begin{array}{c}0.037 \\
(0.709)\end{array}$ & $\begin{array}{l}0.0412 \\
(0.680)\end{array}$ & $\begin{array}{c}-0.0966 \\
(0.571)\end{array}$ & $\begin{array}{l}0.1456 \\
(0.412)\end{array}$ & $\begin{array}{l}0.0392 \\
(0.821)\end{array}$ \\
\hline Investment & $\begin{array}{l}-0.5585 \\
(0.237)\end{array}$ & $\begin{array}{l}0.1774 \\
(0.752)\end{array}$ & $\begin{array}{l}0.1488 \\
(0.787)\end{array}$ & $\begin{array}{l}-0.7413 \\
(0.322)\end{array}$ & $\begin{array}{l}1.0211 \\
(0.411)\end{array}$ & $\begin{array}{l}-0.4175 \\
(0.732)\end{array}$ \\
\hline Earnings volatility & $\begin{array}{c}1.1513 * * * \\
(0.000)\end{array}$ & $\begin{array}{c}-0.6645^{* *} \\
(0.045)\end{array}$ & $\begin{array}{l}-0.1934 \\
(0.561)\end{array}$ & $\begin{array}{c}1.7253 * * * \\
(0.000)\end{array}$ & $\begin{array}{c}-1.6647 * * \\
(0.026)\end{array}$ & $\begin{array}{l}-0.0209 \\
(0.975)\end{array}$ \\
\hline Return on assets & $\begin{array}{l}0.2140 \\
(0.419)\end{array}$ & $\begin{array}{l}0.1223 \\
(0.665)\end{array}$ & $\begin{array}{l}-0.2854 \\
(0.226)\end{array}$ & $\begin{array}{l}0.7489 \\
(0.134)\end{array}$ & $\begin{array}{l}-0.7407 \\
(0.293)\end{array}$ & $\begin{array}{l}0.0590 \\
(0.920)\end{array}$ \\
\hline Leverage & $\begin{array}{c}-0.4136 \\
(0.772)\end{array}$ & $\begin{array}{c}2.5502 * \\
(0.062)\end{array}$ & $\begin{array}{c}-1.6393 \\
(0.191)\end{array}$ & $\begin{array}{c}-0.8818 \\
(0.714)\end{array}$ & $\begin{array}{c}6.4015^{* *} \\
(0.037)\end{array}$ & $\begin{array}{c}-4.3922 * \\
(0.100)\end{array}$ \\
\hline $\operatorname{LR} \chi 2$ & $\begin{array}{c}158.06^{* * * *} \\
(0.000)\end{array}$ & $\begin{array}{c}76.66 * * * \\
(0.000)\end{array}$ & $\begin{array}{c}25.33 \\
(0.150)\end{array}$ & $\begin{array}{c}116.25 * * * \\
(0.000)\end{array}$ & $\begin{array}{c}44.40 * * * \\
(0.001)\end{array}$ & $\begin{array}{c}14.71 \\
(0.741)\end{array}$ \\
\hline Log pseudo-likelihood & -1287.2515 & -1425.8806 & -1372.4889 & -996.9980 & -1332.4221 & -1105.0448 \\
\hline $\begin{array}{l}\text { Partial F-statistic for } \\
\text { first stage leverage } \\
\text { regression }\end{array}$ & & $\begin{array}{c}4.16^{* * * *} \\
(0.000)\end{array}$ & & & $\begin{array}{l}3.15 * * * \\
(0.000)\end{array}$ & \\
\hline No of observations & 2248 & 2248 & 2248 & 2050 & 2050 & 2050 \\
\hline
\end{tabular}


Table 5

Distribution of loan announcing firms over time

The table reports the yearly distribution of announcements of debt offerings for a sample of 400 firms listed in the FTSE-350 index of the London Stock Exchange (LSE) between 2000 and 2012. Loans announcements are made in the subsequent financial year. Sample construction is described in Table 1. Results are reported separately for issuance of public bonds, syndicated bank loans, bilateral bank loans, and non-bank private debt. Panel A presents our initial sample of loan announcements across announcing years and source of borrowing. Panel B excludes firm years where firms borrow from more than one source during the financial year. In years where firms have multiple loans from a single source during the financial year we include these in our sample and use the loan characteristics from the first announcement during the financial year.

\begin{tabular}{|c|c|c|c|c|c|}
\hline Year & Public debt & Bank loan & $\begin{array}{c}\text { Syndicated bank } \\
\text { loan }\end{array}$ & $\begin{array}{c}\text { Bilateral bank } \\
\text { loan }\end{array}$ & $\begin{array}{l}\text { Non-bank } \\
\text { private debt }\end{array}$ \\
\hline \multicolumn{6}{|c|}{ Panel A: Distribution of debt financing sources over time } \\
\hline 2001 & $36[10.81 \%]$ & $35[4.20 \%]$ & $32[4.80 \%]$ & $3[1.80 \%]$ & $17[8.59 \%]$ \\
\hline 2002 & $38[11.41 \%]$ & $43[5.16 \%]$ & $37[5.55 \%]$ & $6[3.59 \%]$ & $22[11.11 \%]$ \\
\hline 2003 & $42[12.61 \%]$ & $55[6.59 \%]$ & $52[7.80 \%]$ & $3[1.80 \%]$ & $25[12.63 \%]$ \\
\hline 2004 & $38[11.41 \%]$ & $77[9.23 \%]$ & $70[10.49 \%]$ & $7[4.19 \%]$ & $11[5.56 \%]$ \\
\hline 2005 & $21[6.31 \%]$ & $91[10.91 \%]$ & $78[11.69 \%]$ & $13[7.78 \%]$ & $11[5.56 \%]$ \\
\hline 2006 & $35[10.51 \%]$ & $69[8.13 \%]$ & $63[9.45 \%]$ & $6[3.59 \%]$ & $23[11.62 \%]$ \\
\hline 2007 & $36[10.81 \%]$ & $63[7.55 \%]$ & $53[7.95 \%]$ & $10[5.99 \%]$ & $18[9.09 \%]$ \\
\hline 2008 & $30[9.01 \%]$ & $64[7.67 \%]$ & $49[7.35 \%]$ & $15[8.98 \%]$ & $16[8.08 \%]$ \\
\hline 2009 & $16[4.80 \%]$ & $45[5.40 \%]$ & $29[4.35 \%]$ & $16[9.58 \%]$ & $11[5.56 \%]$ \\
\hline 2010 & $6[1.80 \%]$ & $67[8.03 \%]$ & $54[8.10 \%]$ & $13[7.78 \%]$ & $14[7.07 \%]$ \\
\hline 2011 & $9[2.70 \%]$ & $102[12.23 \%]$ & $70[10.49 \%]$ & $32[19.16 \%]$ & $12[6.06 \%]$ \\
\hline 2012 & $15[4.50 \%]$ & $62[7.43 \%]$ & $38[5.70 \%]$ & $24[14.37 \%]$ & $10[5.05 \%]$ \\
\hline 2013 & $11[3.30 \%]$ & $61[7.31 \%]$ & $42[6.30 \%]$ & $19[11.38 \%]$ & $8[4.04 \%]$ \\
\hline Total & $333[100.00 \%]$ & $834[100.00 \%]$ & $667[100.00 \%]$ & $167[100.00 \%]$ & $198[100.00 \%]$ \\
\hline \multicolumn{6}{|c|}{ Panel B: Distribution of single issuing firms years over time } \\
\hline 2001 & $14[10.77 \%]$ & $10[2.30 \%]$ & $10[2.83 \%]$ & $0[0.00 \%]$ & $6[9.38 \%]$ \\
\hline 2002 & $12[9.23 \%]$ & $17[3.91 \%]$ & $15[4.25 \%]$ & $2[2.44 \%]$ & $6[9.38 \%]$ \\
\hline 2003 & $12[9.23 \%]$ & $23[5.29 \%]$ & $23[6.52 \%]$ & $0[0.00 \%]$ & $9[14.06 \%]$ \\
\hline 2004 & $15[11.53 \%]$ & $27[6.21 \%]$ & $25[7.08 \%]$ & $2[2.44 \%]$ & $2[3.13 \%]$ \\
\hline 2005 & $7[5.38 \%]$ & $41[9.43 \%]$ & $38[10.76 \%]$ & $3[3.66 \%]$ & $3[4.69 \%]$ \\
\hline 2006 & $16[12.31 \%]$ & $29[6.67 \%]$ & $28[7.93 \%]$ & $1[1.22 \%]$ & $7[10.94 \%]$ \\
\hline 2007 & $15[11.54 \%]$ & $34[7.82 \%]$ & $31[8.78 \%]$ & $3[3.66 \%]$ & $5[7.81 \%]$ \\
\hline 2008 & $13[10.00 \%]$ & $30[6.90 \%]$ & $26[7.37 \%]$ & $4[4.88 \%]$ & $4[6.25 \%]$ \\
\hline 2009 & $7[5.38 \%]$ & $23[5.29 \%]$ & $16[4.53 \%]$ & $7[8.54 \%]$ & $4[6.25 \%]$ \\
\hline 2010 & $1[0.77 \%]$ & $45[10.34 \%]$ & $37[10.46 \%]$ & $8[9.75 \%]$ & $5[7.81 \%]$ \\
\hline 2011 & $2[1.54 \%]$ & $72[16.55 \%]$ & $49[13.88 \%]$ & $23[28.05 \%]$ & $5[7.81 \%]$ \\
\hline 2012 & $11[8.46 \%]$ & $41[9.43 \%]$ & $26[7.37 \%]$ & $15[18.29 \%]$ & $4[6.25 \%]$ \\
\hline 2013 & $5[3.85 \%]$ & $43[9.89 \%]$ & $29[8.22 \%]$ & $14[17.07 \%]$ & $4[6.25 \%]$ \\
\hline Total & $130[100.00 \%]$ & $435[100.00 \%]$ & $353[100.00 \%]$ & $82[100.00 \%]$ & $64[100.00 \%]$ \\
\hline
\end{tabular}


Table 6

Firm and loan characteristics for marginal borrowing decisions

This table presents mean (median) comparisons for firms borrowing from public, syndicated bank, bilateral bank, and non-bank private sources for 400 firms listed in the FTSE-350 index of the London Stock Exchange (LSE) between 2000 and 2012. All firm characteristics are measured at the year-end prior to the loan announcement. Credit quality is based on low interest coverage and is a dummy variable set to one where the interest coverage ratio is less than 0.8 , or less than 1 in two consecutive years. Loan size is the value of the loan deflated to the year 2000. Loan maturity is measured as the years to maturity for each loan. $\triangle G D P$ is the percentage change in gross domestic product during the quarter where the debt announcement was made. Libor is the United Kingdom Interbank 3 month offer rate on the date that the announcement was made expressed in percentage terms. Term spread is defined as the spread between 10-year UK Government bonds and 3-month T-bills, also expressed in percentage terms. Bank dependent is a dummy set to one where the proportion of outstanding bank debt is greater than the median for sample firms and the firm has no public debt, and zero otherwise. Public debt outstanding is a dummy set to one if the firm has any public debt outstanding, and zero otherwise. Sample construction and all remaining variable definitions are provided in Table 1. Superscripts are significantly different from the mean (median) or fraction where appropriate in the corresponding numbered column at the 5\% level or greater. The significance of the difference in means is determined using a t-test of means. The significance of the differences in medians is determined in using the Kruskal-Wallis Test, and the significance of the differences in proportions is determined using the Wilcoxon Rank Sum Test.

\begin{tabular}{|c|c|c|c|c|}
\hline & $\begin{array}{l}\text { Public debt } \\
\quad(\mathrm{N}=130)\end{array}$ & $\begin{array}{c}\text { Syndicated bank } \\
\text { loan } \\
(\mathrm{N}=353)\end{array}$ & $\begin{array}{c}\text { Bilateral bank } \\
\text { loan } \\
(\mathrm{N}=82) \\
\end{array}$ & $\begin{array}{c}\text { Non-bank private } \\
\text { debt } \\
(\mathrm{N}=64)\end{array}$ \\
\hline & $(1)$ & (2) & (3) & $(4)$ \\
\hline \multirow{2}{*}{ Firm size } & $12,114^{2,3,4}$ & $3,075^{1,3,4}$ & $1,971^{1,2}$ & $2,027^{1,2}$ \\
\hline & $(5,460)^{2,4}$ & $(1,373)^{1,3}$ & $(773)^{2,4}$ & $(1,457)^{1,3}$ \\
\hline \multirow{2}{*}{ Firm age } & 47.68 & 44.19 & 39.56 & 43.33 \\
\hline & $(30.50)$ & $(27.00)$ & $(25.00)$ & $(25.50)$ \\
\hline \multirow{2}{*}{ Fixed assets ratio } & $0.36^{2,3,4}$ & $0.29^{1,4}$ & $0.27^{1}$ & $0.21^{1,2}$ \\
\hline & $(0.29)^{2,3,4}$ & $(0.21)^{1,4}$ & $(0.19)^{1}$ & $(0.14)^{1,2}$ \\
\hline Specialized industry & 0.07 & 0.16 & 0.13 & 0.14 \\
\hline \multirow{2}{*}{ Investment } & 0.07 & 0.05 & 0.06 & 0.06 \\
\hline & $(0.05)^{4}$ & $(0.04)$ & $(0.05)$ & $(0.04)^{1}$ \\
\hline \multirow{2}{*}{ Earnings volatility } & $0.03^{2}$ & $0.04^{1}$ & 0.03 & 0.03 \\
\hline & $(0.02)^{2}$ & $(0.02)^{1}$ & $(0.02)$ & $(0.02)$ \\
\hline \multirow{2}{*}{ Leverage } & $0.31^{3,4}$ & $0.30^{3}$ & $0.22^{1,2}$ & $0.26^{1}$ \\
\hline & $(0.29)^{2,3}$ & $(0.23)^{1,3}$ & $(0.20)^{1,2}$ & $(0.25)$ \\
\hline \multirow{2}{*}{ Return on assets } & 0.15 & 0.12 & 0.14 & 0.14 \\
\hline & $(0.13)$ & $(0.13)$ & $(0.13)$ & $(0.13)$ \\
\hline Credit quality & 0.09 & $0.14^{4}$ & 0.09 & $0.06^{2}$ \\
\hline \multirow{2}{*}{ Loan size (£millions) } & $250^{2,4}$ & $387^{1,3,4}$ & $226^{2,4}$ & $99^{1,2,3}$ \\
\hline & $(196)^{2,4}$ & $(274)^{1,3,4}$ & $(195)^{2,4}$ & $(70)^{1,2,3}$ \\
\hline \multirow{2}{*}{ Loan size / total assets } & $0.07^{2,3}$ & $0.25^{1,4}$ & $0.25^{1,4}$ & $0.06^{2,3}$ \\
\hline & $(0.03)^{2,3}$ & $(0.21)^{1,4}$ & $(0.18)^{1,4}$ & $(0.03)^{2,3}$ \\
\hline \multirow{2}{*}{ Loan maturity } & $12.10^{2,3,4}$ & $4.01^{1,4}$ & $3.72^{1,4}$ & $8.55^{1,2,3}$ \\
\hline & $(7.42)^{2,3}$ & $(5.00)^{1,4}$ & $(4.04)^{1,4}$ & $(10.00)^{2,3}$ \\
\hline \multirow{2}{*}{$\Delta \mathrm{GDP}$} & $0.51^{3}$ & $0.45^{3}$ & $0.21^{1,2}$ & 0.43 \\
\hline & $(0.59)^{3}$ & $(0.58)^{3}$ & $(0.45)^{1,2,4}$ & $(0.65)^{3}$ \\
\hline \multirow{2}{*}{ Libor } & $3.99^{2,3,4}$ & $3.06^{1,3}$ & $1.59^{1,2,4}$ & $3.36^{1,3}$ \\
\hline & $(4.55)^{2,3,4}$ & $(3.63)^{1,3}$ & $(0.83)^{1,2,4}$ & $(3.95)^{1,3}$ \\
\hline \multirow{2}{*}{ Term spread } & $0.57^{2,3,4}$ & $1.10^{1,3}$ & $1.89^{1,2,4}$ & $0.96^{1,3}$ \\
\hline & $(0.37)^{2,3,4}$ & $(0.98)^{1,3}$ & $(2.12)^{1,2,4}$ & $(0.90)^{1,3}$ \\
\hline \multirow{2}{*}{ Percentage debt due in excess of 1 year } & $0.77^{3}$ & 0.73 & $0.66^{1,4}$ & $0.77^{3}$ \\
\hline & $(0.83)$ & $(0.87)$ & $(0.83)$ & $(0.89)$ \\
\hline Fraction of bank dependent firms & $0.07^{2,3,4}$ & $0.38^{1}$ & $0.45^{1}$ & $0.34^{1}$ \\
\hline Fraction with public debt outstanding & $0.81^{2,3,4}$ & $0.45^{1,3}$ & $0.32^{1,2}$ & $0.41^{1}$ \\
\hline
\end{tabular}


Table 7

Analysis of new debt issues relative to existing borrowing sources

This table reports the number (proportion) of firm year observations of public debt, syndicated bank loans, bilateral bank loans, and non-bank private debt issues sorted by existing debt for a sample of 400 firms listed on the FTSE350 index of the London Stock Exchange (LSE) between 2000 and 2012. Sample construction is described in Table 1. Sample issuers are split into five groups; issuers with both public and non-bank private debt outstanding, issuers with public debt outstanding, but no non-bank private debt outstanding, issuers with non-bank private debt outstanding, but no public debt outstanding, issuers with neither public or non-bank private debt outstanding, and issuers with no outstanding debt.

\begin{tabular}{lcccccc}
\hline \multicolumn{1}{c}{$\begin{array}{c}\text { Prior public } \\
\text { and non- } \\
\text { bank private } \\
\text { debt } \\
\text { outstanding }\end{array}$} & $\begin{array}{c}\text { Prior public } \\
\text { debt } \\
\text { outstanding, } \\
\text { but no non- } \\
\text { bank private } \\
\text { debt } \\
\text { outstanding }\end{array}$ & $\begin{array}{c}\text { Prior non- } \\
\text { bank private } \\
\text { debt } \\
\text { outstanding, } \\
\text { but no public } \\
\text { debt } \\
\text { outstanding }\end{array}$ & $\begin{array}{c}\text { No public or } \\
\text { non-bank } \\
\text { private debt } \\
\text { outstanding }\end{array}$ & $\begin{array}{c}\text { No debt } \\
\text { outstanding }\end{array}$ & Total \\
\hline Public debt & $45(0.35)$ & $60(0.32)$ & $17(0.13)$ & $4(0.03)$ & $4(0.19)$ & $130(0.21)$ \\
Syndicated bank loan & $66(0.51)$ & $94(0.50)$ & $77(0.57)$ & $106(0.68)$ & $10(0.48)$ & $353(0.56)$ \\
Bilateral bank loan & $11(0.08)$ & $15(0.08)$ & $19(0.14)$ & $30(0.19)$ & $7(0.33)$ & $82(0.13)$ \\
Non-bank private debt & $8(0.06)$ & $18(0.10)$ & $22(0.16)$ & $16(0.10)$ & $0(0.00)$ & $64(0.10)$ \\
Total & $130(1.00)$ & $187(1.00)$ & $135(1.00)$ & $156(1.00)$ & $21(1.00)$ & $629(1.00)$ \\
\hline
\end{tabular}


Table 8

Nested logit regressions of borrowing source determinants conditional on choice between bonds and loans

This table reports nested logit regressions of borrowing source between public, syndicated bank, bilateral bank, and non-bank private sources for a sample of 400 firms listed in the FTSE-350 index of the London Stock Exchange (LSE) between 2000 and 2012. All firm characteristics are measured at the financial year end prior to the issue announcement. Sample construction and variable definitions are provided in Tables 1 and 5. P-values derived from standard errors clustered at the firm level are reported in parentheses. $* * *, * *$, and * denote the parameters are significant at the $1 \%, 5 \%$, and $10 \%$ levels respectively.

\begin{tabular}{|c|c|c|c|}
\hline & \multirow{2}{*}{$\begin{array}{c}\text { First Stage: security choice } \\
\text { Loan versus bond }\end{array}$} & \multicolumn{2}{|c|}{ Second Stage: number of lenders } \\
\hline & & $\begin{array}{l}\text { Non-bank private debt } \\
\text { versus public debt }\end{array}$ & $\begin{array}{l}\text { Bilateral bank loan } \\
\text { versus syndicated } \\
\text { bank loan }\end{array}$ \\
\hline & $(1)$ & $(2)$ & (3) \\
\hline \multirow{2}{*}{ Ln (Firm size) } & $-2.0804 * * *$ & $0.2111 * * *$ & 0.0267 \\
\hline & $(0.000)$ & $(0.005)$ & $(0.699)$ \\
\hline \multirow{2}{*}{ Ln (Firm age) } & 0.0253 & 0.0124 & 0.0657 \\
\hline & $(0.940)$ & $(0.890)$ & $(0.584)$ \\
\hline \multirow{2}{*}{ Fixed assets ratio } & $4.9638 * * *$ & $-1.5923 * * *$ & -0.6198 \\
\hline & $(0.006)$ & $(0.007)$ & $(0.283)$ \\
\hline \multirow{2}{*}{ Specialized industry } & -0.6598 & 0.4312 & -0.2058 \\
\hline & $(0.728)$ & $(0.252)$ & $(0.581)$ \\
\hline \multirow{2}{*}{ Investment } & 3.9594 & -2.3562 & 0.7732 \\
\hline & $(0.629)$ & $(0.247)$ & $(0.791)$ \\
\hline \multirow{2}{*}{ Earnings volatility } & 2.6729 & -0.5464 & $-6.2265^{*}$ \\
\hline & $(0.816)$ & $(0.852)$ & $(0.090)$ \\
\hline \multirow{2}{*}{$\mathrm{ROA}$} & -9.8876 & $3.0679 *$ & 1.8843 \\
\hline & $(0.101)$ & $(0.065)$ & $(0.304)$ \\
\hline \multirow{2}{*}{ Leverage } & 1.9330 & $-1.4138 *$ & -0.3376 \\
\hline & $(0.511)$ & $(0.075)$ & $(0.666)$ \\
\hline \multirow{2}{*}{ Credit quality } & $-4.9704 * *$ & $1.0383 * *$ & -0.3718 \\
\hline & $(0.050)$ & $(0.021)$ & $(0.407)$ \\
\hline \multirow{2}{*}{ Ln (Loan size) } & $2.9570 * * *$ & $-0.3344 * * *$ & -0.0668 \\
\hline & $(0.000)$ & $(0.000)$ & $(0.330)$ \\
\hline \multirow{2}{*}{ Loan maturity } & $-0.7403 * * *$ & $-0.0331 *$ & 0.0076 \\
\hline & $(0.001)$ & $(0.057)$ & $(0.957)$ \\
\hline \multirow{2}{*}{ Libor } & -1.4348 & 0.1284 & $-0.3382 * *$ \\
\hline & $(0.103)$ & $(0.294)$ & $(0.016)$ \\
\hline \multirow{2}{*}{ Term spread } & $-1.8570 *$ & $0.3951 * *$ & 0.0360 \\
\hline & $(0.065)$ & $(0.040)$ & $(0.874)$ \\
\hline \multirow{2}{*}{ Proportion long-term debt } & $-3.9720 * *$ & 0.7732 & -0.2024 \\
\hline & $(0.033)$ & $(0.146)$ & $(0.688)$ \\
\hline \multirow{2}{*}{ Bank dependent } & -1.2481 & $0.5371 *$ & 0.2375 \\
\hline & $(0.321)$ & $(0.062)$ & $(0.345)$ \\
\hline $\operatorname{LR} \chi^{2}$ & $\begin{array}{l}893.32 \\
(0.000)\end{array}$ & & \\
\hline Pseudo $\mathrm{R}^{2}$ & 0.5122 & & \\
\hline Log likelihood & -425.32 & & \\
\hline No of observations & 629 & & \\
\hline
\end{tabular}


Table 9

Nested logit regressions of borrowing source determinants conditional on choice between dispersed and concentrated lenders

This table reports nested logit regressions of borrowing source between public, syndicated bank, bilateral bank, and non-bank private sources for a sample of 400 firms listed in the FTSE-350 index of the London Stock Exchange (LSE) between 2000 and 2012. All firm characteristics are measured at the financial year end prior to the issue announcement. Sample construction and variable definitions are provided in Tables 1 and 5. P-values derived from standard errors clustered at the firm level are reported in parentheses. $* * *, * *$, and * denote the parameters are significant at the $1 \%, 5 \%$, and $10 \%$ levels respectively.

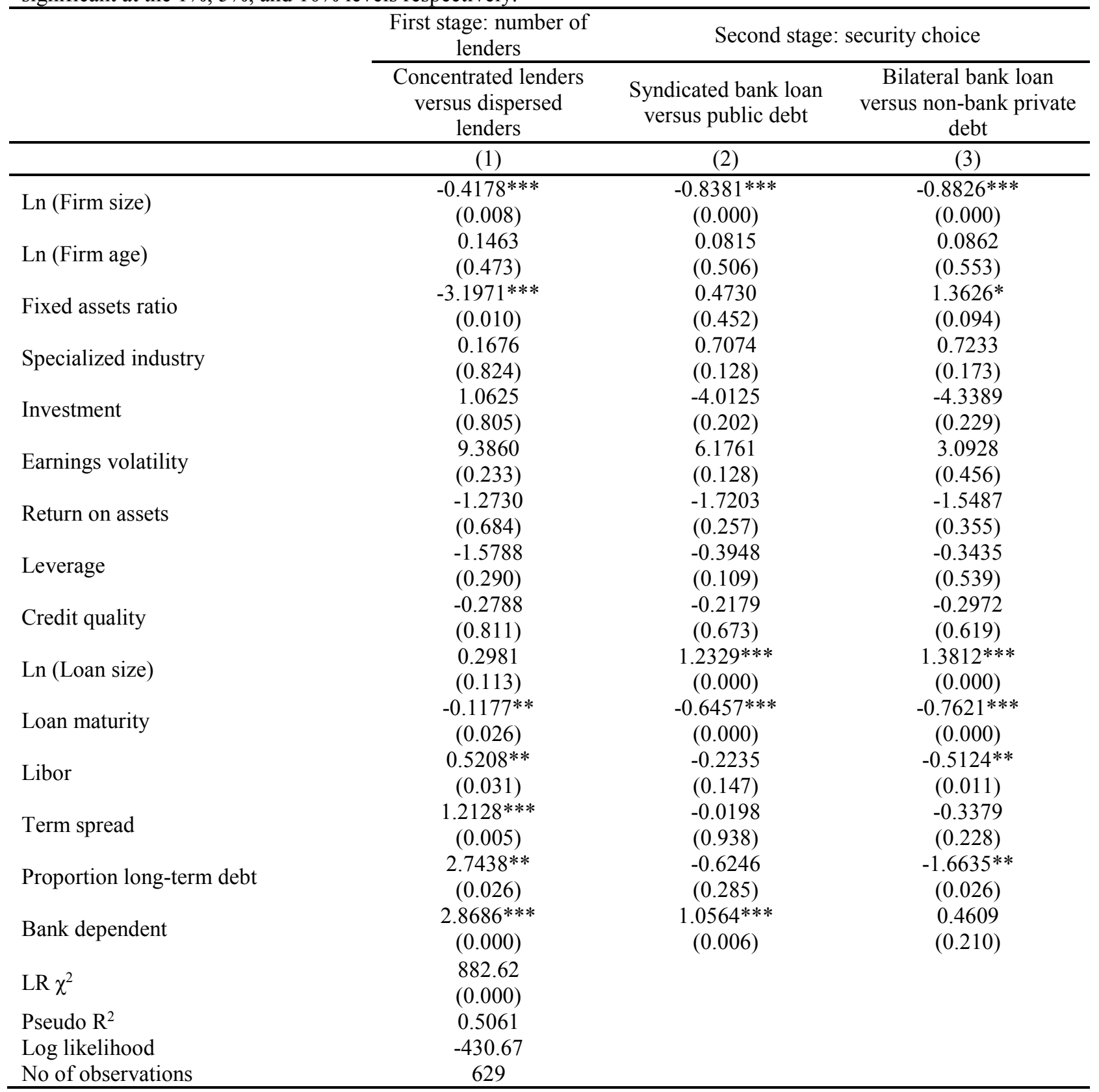




\section{Table 10}

\section{Determinants of balance sheet debt source surrounding the global financial crisis}

This table presents the results of second stage instrumental variable Tobit regressions of debt source for a sample of 400 firms listed in the FTSE-350 index of the London Stock Exchange (LSE) between 2000 and 2012, split into two periods 2000 to 2007 and 2008 to 2012. Sample construction and variable definitions are provided in Table 1. The dependent variable is censored between zero and one. The unreported first stage regression of the determinants of leverage and long-term leverage use cash divided by total assets as the instrumental variable. Year dummy variables are included in the regressions but are not reported for brevity. P-values derived from standard errors clustered at the firm level are reported in parentheses. $* * *, * *$, and $*$ denote the parameters are significant at the $1 \%, 5 \%$, and $10 \%$ levels respectively.

\begin{tabular}{|c|c|c|c|c|c|c|}
\hline & $\begin{array}{l}\text { Public debt } \\
\text { to total debt }\end{array}$ & $\begin{array}{l}\text { Bank debt } \\
\text { to total debt }\end{array}$ & $\begin{array}{l}\text { Non-bank } \\
\text { private debt } \\
\text { to total debt }\end{array}$ & $\begin{array}{l}\text { Long-term } \\
\text { public debt } \\
\text { to total } \\
\text { long-term } \\
\text { debt }\end{array}$ & $\begin{array}{l}\text { Long-term } \\
\text { bank debt } \\
\text { to total } \\
\text { long-term } \\
\text { debt }\end{array}$ & $\begin{array}{c}\text { Long-term } \\
\text { non-bank } \\
\text { private debt } \\
\text { to total } \\
\text { long-term } \\
\text { debt }\end{array}$ \\
\hline & (1) & (2) & (3) & (4) & (5) & (6) \\
\hline Intercept & $\begin{array}{c}-5.9741 * * * \\
(0.000)\end{array}$ & $\begin{array}{c}5.2816^{* * *} \\
(0.000)\end{array}$ & $\begin{array}{c}-1.9257^{* * *} \\
(0.001)\end{array}$ & $\begin{array}{c}-8.3907 * * * \\
(0.000)\end{array}$ & $\begin{array}{c}5.9583 * * * \\
(0.000)\end{array}$ & $\begin{array}{c}-1.2056 \\
(0.363)\end{array}$ \\
\hline Ln (Firm size) & $\begin{array}{c}0.2840 * * * \\
(0.000)\end{array}$ & $\begin{array}{c}-0.2437 * * * \\
(0.000)\end{array}$ & $\begin{array}{c}0.1091 * * * \\
(0.003)\end{array}$ & $\begin{array}{c}0.3858^{* * *} \\
(0.000)\end{array}$ & $\begin{array}{c}-0.3160 * * * \\
(0.000)\end{array}$ & $\begin{array}{c}0.1079^{*} \\
(0.051)\end{array}$ \\
\hline Ln (Firm age) & $\begin{array}{l}-0.0102 \\
(0.754)\end{array}$ & $\begin{array}{l}0.0118 \\
(0.759)\end{array}$ & $\begin{array}{l}-0.0043 \\
(0.912)\end{array}$ & $\begin{array}{l}0.0092 \\
(0.867)\end{array}$ & $\begin{array}{l}0.0710 \\
(0.386)\end{array}$ & $\begin{array}{l}-0.0810 \\
(0.369)\end{array}$ \\
\hline Fixed assets ratio & $\begin{array}{l}0.2373 \\
(0.328)\end{array}$ & $\begin{array}{l}-0.1930 \\
(0.381)\end{array}$ & $\begin{array}{l}0.0831 \\
(0.714)\end{array}$ & $\begin{array}{l}0.3269 \\
(0.474)\end{array}$ & $\begin{array}{l}-0.8315 \\
(0.134)\end{array}$ & $\begin{array}{l}0.6223 \\
(0.282)\end{array}$ \\
\hline Specialized industry & $\begin{array}{l}-0.0156 \\
(0.904)\end{array}$ & $\begin{array}{l}-0.0317 \\
(0.751)\end{array}$ & $\begin{array}{l}0.0695 \\
(0.492)\end{array}$ & $\begin{array}{l}-0.0601 \\
(0.748)\end{array}$ & $\begin{array}{l}0.0204 \\
(0.912)\end{array}$ & $\begin{array}{l}0.1018 \\
(0.589)\end{array}$ \\
\hline Investment & $\begin{array}{l}-0.2175 \\
(0.677)\end{array}$ & $\begin{array}{l}-0.1096 \\
(0.823)\end{array}$ & $\begin{array}{l}0.3154 \\
(0.569)\end{array}$ & $\begin{array}{l}-0.3060 \\
(0.704)\end{array}$ & $\begin{array}{l}0.5631 \\
(0.601)\end{array}$ & $\begin{array}{l}-0.2809 \\
(0.835)\end{array}$ \\
\hline Earnings volatility & $\begin{array}{c}1.0401 * * * \\
(0.001)\end{array}$ & $\begin{array}{c}-0.7548^{* *} \\
(0.015)\end{array}$ & $\begin{array}{l}0.0315 \\
(0.923)\end{array}$ & $\begin{array}{c}1.6007 * * * \\
(0.001)\end{array}$ & $\begin{array}{c}-1.8964 * * \\
(0.012)\end{array}$ & $\begin{array}{l}0.4597 \\
(0.519)\end{array}$ \\
\hline Return on assets & $\begin{array}{l}0.0288 \\
(0.897)\end{array}$ & $\begin{array}{l}0.0304 \\
(0.901)\end{array}$ & $\begin{array}{l}-0.0590 \\
(0.800)\end{array}$ & $\begin{array}{l}0.3412 \\
(0.452)\end{array}$ & $\begin{array}{l}-0.8698 \\
(0.202)\end{array}$ & $\begin{array}{l}0.6148 \\
(0.366)\end{array}$ \\
\hline Leverage & $\begin{array}{l}-0.4404 \\
(0.797)\end{array}$ & $\begin{array}{l}2.1218 \\
(0.157)\end{array}$ & $\begin{array}{l}-1.8471 \\
(0.259)\end{array}$ & $\begin{array}{l}-0.2608 \\
(0.927)\end{array}$ & $\begin{array}{c}6.0849^{*} \\
(0.080)\end{array}$ & $\begin{array}{l}-5.7229 \\
(0.120)\end{array}$ \\
\hline $\operatorname{LR} \chi^{2}$ & $\begin{array}{c}102.11 * * * \\
(0.000)\end{array}$ & $\begin{array}{c}70.38 * * * \\
(0.000)\end{array}$ & $\begin{array}{c}15.53 \\
(0.4138)\end{array}$ & $\begin{array}{c}86.16^{* * *} \\
(0.000)\end{array}$ & $\begin{array}{c}38.92 * * * \\
(0.007)\end{array}$ & $\begin{array}{c}7.02 \\
(0.957)\end{array}$ \\
\hline $\begin{array}{l}\text { Log pseudo-likelihood } \\
\text { Partial F-statistic for first } \\
\text { stage leverage regression }\end{array}$ & -898.1968 & $\begin{array}{c}-970.2065 \\
2.88 \\
(0.0003)\end{array}$ & -964.1450 & -670.0609 & $\begin{array}{c}-909.9248 \\
2.70 \\
(0.0007)\end{array}$ & -762.0340 \\
\hline No of observations & 1533 & 1533 & 1533 & 1384 & 1384 & 1384 \\
\hline
\end{tabular}




\begin{tabular}{|c|c|c|c|c|c|c|}
\hline \multicolumn{7}{|c|}{ Panel B: Debt source 2008-20012 } \\
\hline & $\begin{array}{l}\text { Public debt } \\
\text { to total debt }\end{array}$ & $\begin{array}{l}\text { Bank debt } \\
\text { to total debt }\end{array}$ & $\begin{array}{l}\text { Non-bank } \\
\text { private debt } \\
\text { to total debt }\end{array}$ & $\begin{array}{l}\text { Long-term } \\
\text { public debt } \\
\text { to total } \\
\text { long-term } \\
\text { debt }\end{array}$ & $\begin{array}{l}\text { Long-term } \\
\text { bank debt } \\
\text { to total } \\
\text { long-term } \\
\text { debt }\end{array}$ & $\begin{array}{l}\text { Long-term } \\
\text { non-bank } \\
\text { private debt } \\
\text { to total } \\
\text { long-term } \\
\text { debt }\end{array}$ \\
\hline & (1) & (2) & (3) & (4) & (5) & (6) \\
\hline Intercept & $\begin{array}{c}-7.6225 * * * \\
(0.000)\end{array}$ & $\begin{array}{c}5.6914 * * * \\
(0.000)\end{array}$ & $\begin{array}{l}-1.2229 \\
(0.170)\end{array}$ & $\begin{array}{c}-9.7990 * * * \\
(0.000)\end{array}$ & $\begin{array}{c}6.5197 * * * \\
(0.002)\end{array}$ & $\begin{array}{r}-1.1540 \\
(0.316)\end{array}$ \\
\hline Ln (Firm size) & $\begin{array}{c}0.3224^{* * *} \\
(0.000)\end{array}$ & $\begin{array}{c}-0.2460 * * * \\
(0.000)\end{array}$ & $\begin{array}{l}0.0671 \\
(0.112)\end{array}$ & $\begin{array}{c}0.4218 * * * \\
(0.000)\end{array}$ & $\begin{array}{c}-0.3039 * * * \\
(0.003)\end{array}$ & $\begin{array}{l}0.0578 \\
(0.277)\end{array}$ \\
\hline Ln (Firm age) & $\begin{array}{c}0.1904^{* * *} \\
(0.002)\end{array}$ & $\begin{array}{c}-0.2145^{* * *} \\
(0.007)\end{array}$ & $\begin{array}{l}0.0793 \\
(0.239)\end{array}$ & $\begin{array}{c}0.2847 * * * \\
(0.005)\end{array}$ & $\begin{array}{c}-0.3140^{* *} \\
(0.018)\end{array}$ & $\begin{array}{c}0.0891 \\
(0.342)\end{array}$ \\
\hline Fixed assets ratio & $\begin{array}{c}0.6366^{*} \\
(0.081)\end{array}$ & $\begin{array}{l}-0.6111 \\
(0.372)\end{array}$ & $\begin{array}{c}-0.1324 \\
(0.746)\end{array}$ & $\begin{array}{l}1.0563 \\
(0.135)\end{array}$ & $\begin{array}{l}-0.8080 \\
(0.555)\end{array}$ & $\begin{array}{r}-0.2477 \\
(0.676)\end{array}$ \\
\hline Specialized industry & $\begin{array}{l}-0.1081 \\
(0.529)\end{array}$ & $\begin{array}{l}0.2237 \\
(0.223)\end{array}$ & $\begin{array}{l}0.0381 \\
(0.824)\end{array}$ & $\begin{array}{l}-0.2780 \\
(0.332)\end{array}$ & $\begin{array}{l}0.4710 \\
(0.151)\end{array}$ & $\begin{array}{l}0.0936 \\
(0.725)\end{array}$ \\
\hline Investment & $\begin{array}{c}-2.4733 * * \\
(0.013)\end{array}$ & $\begin{array}{l}1.0951 \\
(0.419)\end{array}$ & $\begin{array}{l}-0.1534 \\
(0.889)\end{array}$ & $\begin{array}{c}-3.7212 * * \\
(0.041)\end{array}$ & $\begin{array}{l}2.1740 \\
(0.470)\end{array}$ & $\begin{array}{c}-0.0374 \\
(0.983)\end{array}$ \\
\hline Earnings volatility & $\begin{array}{l}1.3302 \\
(0.182)\end{array}$ & $\begin{array}{l}0.1321 \\
(0.943)\end{array}$ & $\begin{array}{l}-2.1506 \\
(0.124)\end{array}$ & $\begin{array}{l}2.1079 \\
(0.235)\end{array}$ & $\begin{array}{l}-0.8001 \\
(0.814)\end{array}$ & $\begin{array}{l}-2.8370 \\
(0.189)\end{array}$ \\
\hline Return on assets & $\begin{array}{c}1.3545 * * \\
(0.014)\end{array}$ & $\begin{array}{l}0.6094 \\
(0.599)\end{array}$ & $\begin{array}{c}-1.6700 * * \\
(0.028)\end{array}$ & $\begin{array}{c}2.6427 * * \\
(0.017)\end{array}$ & $\begin{array}{l}0.0498 \\
(0.983)\end{array}$ & $\begin{array}{c}-2.0672 * \\
(0.066)\end{array}$ \\
\hline Leverage & $\begin{array}{r}-0.6680 \\
(0.698)\end{array}$ & $\begin{array}{l}3.9228 \\
(0.137)\end{array}$ & $\begin{array}{c}-1.6293 \\
(0.346)\end{array}$ & $\begin{array}{c}-3.4158 \\
(0.357)\end{array}$ & $\begin{array}{l}7.8459 \\
(0.212)\end{array}$ & $\begin{array}{l}-1.5045 \\
(0.639)\end{array}$ \\
\hline LR $\chi^{2}$ & $\begin{array}{c}145.54 * * * \\
(0.000)\end{array}$ & $\begin{array}{c}39.23 * * * \\
(0.000)\end{array}$ & $\begin{array}{l}16.70 \\
(0.117)\end{array}$ & $\begin{array}{c}77.31 * * * \\
(0.000)\end{array}$ & $\begin{array}{c}22.04 * * \\
(0.024)\end{array}$ & $\begin{array}{c}13.54 \\
(0.259)\end{array}$ \\
\hline $\begin{array}{l}\text { Log pseudo-likelihood } \\
\text { Partial F-statistic for first } \\
\text { stage leverage regression }\end{array}$ & -348.1322 & $\begin{array}{c}-415.7813 \\
4.55 \\
(0.0000)\end{array}$ & -378.9433 & -290.1209 & $\begin{array}{c}-363.6940 \\
4.65 \\
(0.0000)\end{array}$ & -315.3671 \\
\hline No of observations & 715 & 715 & 715 & 666 & 666 & 666 \\
\hline
\end{tabular}

